\title{
MEETING MANAGERIAL SKILLS AND ATTITUDE OF SCHOOL MANAGERS COMPARISATION 2009-2021
}

DOI: 10.17261/Pressacademia.2021.1403

RJBM- V.8-ISS.2-2021(7)-140-159

Umit Caliskan' ${ }^{1}$, Sevgi Kalkan²

${ }^{1}$ Pendik Camlik Primary School, Istanbul, Turkey. umitcaliskan34@hotmail.com, ORCID: 0000-0003-3691-8975

2istanbul Yeni Yuzyil University, Faculty Of Economics and Adminisration, Istanbul, Turkey. sevgi.kalkan@yeniyuzyil.edu.tr , ORCID: 0000-0002-9131-4448

\begin{tabular}{l}
\hline Date Received: March 4, $2021 \quad$ Date Accepted: June 5, 2021 \\
\hline To cite this document \\
Caliskan, U., Kalkan, S. (2021). Meeting managerial skills and attitude of school managers comparisation 2009-2021. Research Journal of Business \\
and Management (RJBM), 8(2), 140-159. \\
Permanent link to this document: http://doi.org/10.17261/Pressacademia.2021.1403 \\
Copyright: Published by PressAcademia and limited licensed re-use rights only. \\
\hline
\end{tabular}

\section{ABSTRACT}

Purpose- is to examine the meeting management skills and attitudes of the school managers in our education system and to examine the perceptions of teachers on this issue by making a comparison between 2009 findings and 2021 findings.

Methodology- The research is a basic quantitative field study. Questionnaire was used as a data collection tool. Survey participants were reached using the convenience sampling method. 5-point Likert scales was used for measuring research variables.

Findings- When the meeting management attitudes and skills of the administrators working in schools affiliated to the Ministry of National Education are evaluated according to the opinions of the teachers, it is observed that these opinions differ significantly in terms of gender, educational status and duration of service in the profession. School managers' meeting management skills have differentiated significantly over the years in terms of sub-dimensions such as time management, managing hall facilities, meeting agenda, managing participants and meeting minutes.

Conclusion- According to teachers' perceptions, school managers meeting management skills have a statistically significant difference over the years. Teachers participating in the study in 2021 perceive that school managers' meeting management skills have improved more positively than in 2009. Considering that meeting management skills in the digital environment will gain more importance in the digital transformation processes of education, much more extensive research to be done in this field will benefit literature.

Keywords: School managers, meeting management, teacher perceptions, education, managerial attitudes and skills JEL Codes: 120, 121, M10

\section{OKUL YÖNETICILERININ TOPLANTI YÖNETIMI TUTUM VE BECERILERI 2009-2021 KARŞILAŞTIRMASI}

\section{ÖZET}

Amaç- Eğitim sistemimizde okul yöneticilerinin toplantı yönetimi tutum ve becerilerinden olan toplantı yönetim becerileri, zaman yönetimi, salon tesislerini yönetme, toplantı gündemi, katılımcıları yönetme ve toplantı tutanaklarını yönetme becerilerine ne kadar sahip olduğunu ve öğretmenlerin bu konudaki algılarını 2009 ve 2021 yılı bulgularını karşılaştırarak incelemektir.

Yöntem- Araştırma, nicel bir saha çalışması niteliğinde temel bir araştırmadır. Veri toplama aracı olarak anket kullanılmışır. Kolayda örneklem metoduyla anket katılımcılarına ulaşılmıştır. Araştırmanın değişkenlerini ölçmek için 5'li Likert Tipi ölçek kullanılmıştır.

Bulgular- MEB'e bağlı okullarda görevli yöneticilerin "Toplantı Yönetimi Tutum ve Becerileri” öğretmenlerin görüşlerine göre değerlendirildiğinde cinsiyet, öğrenim durumu ve meslekteki hizmet süresi değişkenleri açısından bu görüşlerin anlamlı düzeyde farklılı gösterdiği görülmüştür. Okul yöneticilerinin toplantı yönetimi becerileri, zaman yönetimi, salon tesislerini yönetme, toplantı gündemi, katılımcıları yönetme ve toplantı tutanakları gibi alt boyutlar açısından yıllar içinde önemli ölçüde farklılık göstermiştir

Sonuç- Öğretmenlerin algılarına göre, okul yöneticilerinin toplantı yönetme becerileri, yıllara göre istatistiksel olarak anlamlı bir farkıllığa sahiptir. Araştırmaya 2021 yılında katılan öğretmenler, okul yöneticilerinin toplantı yönetme becerilerinin 2009 yılına göre zamanı yönetme, salon olanaklarını yönetme, toplantı gündemini yönetme, katılımcıları yönetme, toplantı tutanaklarını yönetme gibi alt boyutlar açısından daha olumlu yönde geliştiği algısındadırlar. Eğitimin dijital dönüşüm süreçlerinde dijital ortamda toplantı yönetme becerilerinin daha çok önem kazanacağı düşünüldğünde bu alanda yapılması gereken çok daha kapsamlı araştırmalar litaratüre fayda sağlayacaktır.

Anahtar Kelimeler: Okul yöneticileri, toplantı yönetimi, öğretmen algıları, eğitim, yönetici tutum ve becerileri JEL Kodları: 120, 121, M10 


\section{GiRiş}

Eğitim bir ülkenin kalkınma serüveninin ilk adımıdır. Eğitim yapılarının temeli okullardır. Öğrenci yapısını yöneten öğretmenler, öğretmen grubunu yöneten, motive eden de okul yöneticileridir. Okul idarecileri eğitim programının uygulanması ve diğer yönetişim işlevlerini de organize ederler. Yöneticilere eğitim ve öğretim etkinliklerinin verimliliğe ve etkililiğe ulaştırılmasında büyük sorumluluklar düşmektedir. Bu amacı gerçekleştirebilmek için öğretmenlerle ve diğer ilgililerle; beraber kararlar almak, kararların uygulanmasını sağlamak; okulda ortaya çıkan problemleri çözmek amacıyla gereken bilimsel yaklaşımları sağlamak üzere toplantılar yapılır. Öğretmenlerin tecrübeleri sonucunda edindiği bilgi, görüş ve deneyimlerini dikkate almadan eğitim reformları planlamak başarısızlığa neden olacaktır. (Yurdakul, Gür, Çelik ve Kurt, 2016). Son yıllarda yapılan bazı bilimsel araştırmalarda (Avcı ve Seferoğlu, 2011; Şişman, 2004; Tümkaya, 2005,) kısıtlayıcı okul kültürü, idare ile çatışma ve örgüt özellikleri gibi etkenlerden dolayı Türkiye'de öğretmenlerin çoğunluğunda tükenmişlik sendromu görülmüştür. Tükenmişliğe sebep olan çatışmaların önüne geçilmesini sağlayabilecek olan toplantıların öğretmen gözünden nasıl algılandığı son derece önemlidir. Yönetmelik gereği en az yılda üç kez yapılması gereken öğretmen kurulları ismi verilen bu toplantılar ile takım ruhu oluşturmak, öğretmenlerin yönetime katkılarını sağlamak üzere yönetişim sorunlarının çözümü için ortam hazırlanmaktadır. (Taymaz, 2003: 167).

Okul sistemini yönetmek ve iyileştirmeler elde etmek için düzenlenen toplantıların başarılı olması açıktır ki, yöneticilerin toplantı yönetimi ile ilgili ilkeleri ve teknikleri iyi bilmelerine ve bu teknikleri uygulamalarına bağlıdır (Dunsing, 1986:55). Bu nedenle çalışmada, okul yöneticilerinin toplantı yönetimi ve becerilerine sahip olup olmadıkları, 2009 ve 2021 yıllarında yapılan saha çalışmasıyla incelenecek ve öğretmen algılarındaki değişim saptanacaktır. Okul yöneticisinin toplantı yönetici becerileri, zaman kontrolünü yönetme, salon olanaklarını yönetme, toplantı gündemini yönetme, katılımcıları yönetme, toplantı tutanaklarını yönetme konlarında tutum ve becerilere yeterli düzeyde sahip olması beklenir. Çalışmanın ilk bölümünde toplantı yönetimine ait özet nitelikte literatür taraması, ikinci bölümünde metododoji ve bulgular, son bölümde ise sonuçlar açıklanmıştır. Çalışmanın literatür kısımında toplantı konusuna genel bir bakışla toplantı yöneticisinin sahip olması gereken toplantı sürecinin yönetimi, toplantı liderliği, toplantı kavramı ve özellikleri üzerinde ayrı ayrı durulmuştur.

Veri toplamak amacıyla nicel yöntemlere ilişkin anket tekniği tercih edilmiştir. Araştırma 2009 ve 2021 yıllarında İstanbul ili Anadolu yakasında bulunan resmi ilköğretim okullarında çalışan eğitim çalışanlarına 47 soruluk bir anket uygulanarak yapılmıştır. Araştırma sonucunda öğretmenlerin lisansüstü eğitim bitirme oranı yıllar ilerledikçe artmasına bağlı olarak memnuniyet oranının düşük çıkması beklenmektedir. Ancak okul yöneticilerinin de kendilerini yenileme imkânları artmıştır. Gerek hizmet içi eğitimlerle ve gerek üniversitelerle yapılan anlaşmalarla düzenlenen yüksek lisans eğitimleri sonucu kendini yenileyen yöneticilerin bu beklentileri karşılama oranı da artabilecektir. Okul yöneticilerinin kendilerini geliştirmesiyle birlikte beklentilerin karşılanacağı ve öğretmenlerin algı düzeylerinde anlamlı farklılıklar ortaya çıkacağı öngörülmektedir.

\section{LITERATÜR ÖZETI}

\subsection{Toplantı Kavramı ve Özellikleri}

Türk Dil Kurumuna göre toplantı; "birden çok kimsenin belirli amaçlarla bir araya gelmesi” olarak tanımlamakta iken Payne (1998:8) "Belli sonuçlara ulaşmak için aktif rolleri olan iki veya daha fazla insanın arasındaki bilgi, görüş ve fikir alışverişi" olarak tanımlar. Toplantı, okullarda öğretmen motivasyonunu ve dolayısıyla öğrenci başarısını arttırmak amaçlı çok çeşitli şekillerde kullanılmakta olan bir organizasyon çeşididir. Özellikle genel, birebir, sorun çözme, bilgi alışverişi, seminer, konferans şeklinde uygulanan toplantıların verimi yönetici tutum ve davranışı ile başarıya ulaşır veya ulaşamaz.

Toplantı zamanının geldiğine kanaat getirmeden toplantı düzenlenmemeli, toplantı zamanı ve gündem katılımcıların katkısı ile belirlenmeli ve tüm süreç öncesinde ve sırasında katılımcıların görüşleri ile sürdürülmelidir. Sırf önceden planlandı diye toplantı düzenlemek doğru bir uygulama değildir. ( Çalışkan,2017:37)

Genellikle toplantılar aşağıdaki nedenler dolayısıyla yapılır (Morgan,2006:17):

- Okul yönetimi ile ilgili bir konuda bilgi vermek ya da yol göstermek için öğretmenlerin tamamını veya bir kısmını bir araya getirmek gerekiyorsa

- Stratejik bir adım atarak yönetimde katılımı sağlamak amacıyla kararların alınmasına ya da herhangi bir sorunun çözümüne öğretmenleri katmak için

- Grubun tamamını ilgilendiren veya çoğunluğun katılımı ile bir sorunu çözüme ulaştırmak gerektiğinde 
- Bir enformasyon, bir başarı ya da bir problem grubun tamamıla paylaşılmak ya da durumdan haberdar edilmek istendiğinde

- Farklı yaklaşımları ya da gündemleri olan diğer grupların katkısına ihtiyaç gösteren bir problemle uğraşıldığında

- $\quad$ Grubun bir toplantıya şiddetle ihtiyacı olduğunu keşfettiyseniz.

Toplantılar amaç, konu, düzenlendikleri yer, katılımcı sayısı, ortaya çıkış biçimi, düzenleyici, düzenlenme sıklığı kategorilerinde sınıflandırılabilir. ( Şekil 1.1)

\section{Şekil 1: Toplantıların Sınıflandırılması}

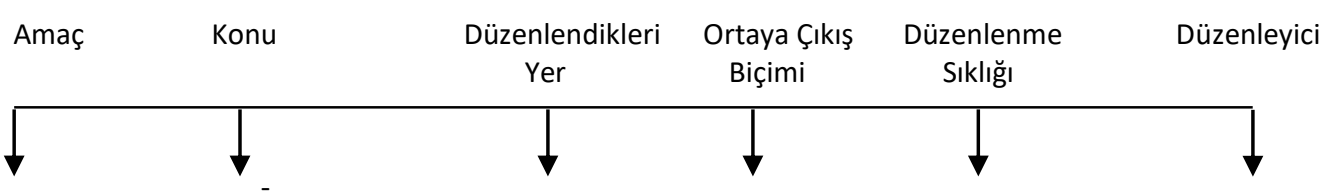

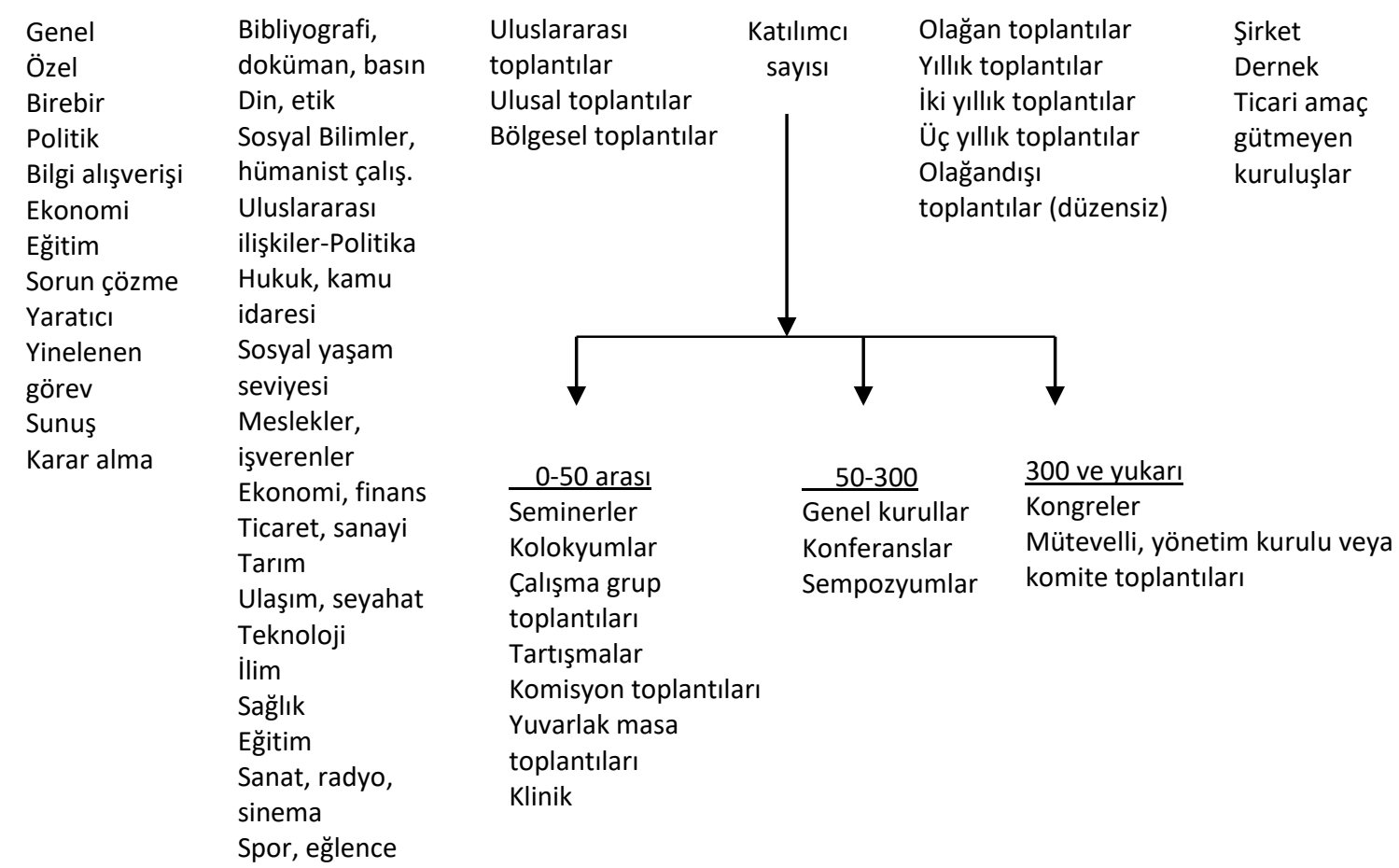

Kaynak: Tavmergen, I. ve Aksakal, E.(2004). “Kongre Ve Toplantı Yönetimi”, s.35

Gündem tüm grubu ilgilendiriyorsa, kararlar ortaklaşa alınmalıysa, grup sizinle toplantı yapmak istiyorsa, çift yönlü bilgi akışı gerekiyorsa (Thomsett,1997:40) toplantı yapılmalıdır.

Toplantı alınan kararlar doğru hedefe işaret ediyor ve toplantı sonrası kurumda sinerji oluşturmuşsa toplantı doğru şeklide ve zamanda yapılmış demektir. Kuralsızlığın boşluğuna dalmadan, önceden konulan kurallar çerçevesinde sürdürülen toplantı planlaması yönetici tarafından yapılmalıdır.

\subsection{Toplantı Liderliği}

Toplantılar bir amaca ulaşmak için kullanılan araçtırlar. Yönetilemeyen, planlanamayan, iyi hazırlanmamış toplantılar, en değerli kaynağımız olan zamanımızı yok etmektedir. Okul yöneticisinin en önemli kozu ve kullanacağı argümanı olan toplantılar, yönetim biliminin ise kalbidir. Toplantılar genelde, motivasyon ve sinerji verirken; bilgilendirici, paylaşımcı ve okulda mutluluk kaynağı 
olmakla beraber, iyi yönetilemediğinde motivasyon bozucu ve sıkıcı olabilir. (Akt. İşsever, Toplantı Yönetimi, 2001) Tam bu noktada yöneticilerin beceri ve tutumları devreye girer ve yönetimsel liderlik özelliği ön plana çıkar. Toplantıların verimli ve kaliteli çıtı alacak biçimde yönetilmesi bilimsel kaidelere uyulduğunda kolaydır. İyi bir hazırlık, eleştirilere açık olmak ve samimiyet ile aşılamayacak sorun yoktur.

İyi bir yönetici toplantıda şu faktörleri kontrol altında tutulmalıdır (Thomset,1997:32): Planlama, toplantıyı yönlendirme, sürecin takibi. Başarı için aşağıdaki üç boyutunun başarıyla yönetilmesi gerekir (Dunsing, 1989:54): Toplantı yönetiminin işlemleri, toplantıdaki sosyal ilişkiler, fiziksel ortam. Sorunlarla başa çıkabilmek için gruplarla yapılan tartışmaları sona erdirmekte kullanılacak yönetmeler şunlardır (Linkemer,1993:52):

1. Öğretmenlerin düşüncelerini ve bizden farklı görüşlerini ortaya çıkarmak için sorular sormak

2. Öğretmenlerin toplantıdan önce fikirlerini not almalarını sağlamak

3. Toplantının iklimini değiştirmek için tüm katılımcıları tartışmaların içine çekmek

4. Uzman(lar)ın görüşlerine yer vermek

5. Yönetici olarak fikir ve düşünceleri en son açıklamak

Ayrıca başarı için verimli ve sağlıklı bir iletişim ve ikna sürecinin sağlanması da gerekir. Okul yöneticisi kuracağı sağlıklı iletişim kanalları yardımıyla önceden sahadan alacağı veriler ile yaptığı hazırlık sayesinde kazanamayacağı toplantı olmayacaktır.

\subsection{Toplantı Sürecinin Yönetimi}

Toplantı yönetim süreci toplantı öncesinde yapılacak planlamayı, hazırlığı, ön toplantıyı, görev dağılımını, katılımcı sürecinin yönetimini, gündemin belirlenmesini, toplantıda ele alınma biçimini ve yönetimini, toplantı mekânının belirlenmesini ve yönetimini, ikram ve bütçeleme basamaklarını başarılı bir şeklide yönetmektir. Toplantı yöneticisi ilk olarak toplantının amaçlarına, hedeflerine, toplantının zamanına ve toplantının şekline karar vermelidir ( İçöz, 1998:206). Hazırlık yapılamadan toplantının başarılı olması mümkün olmadığı gibi yetersiz hazırlık da başarısız toplantıların ana nedenidir. Toplantı sırasında sunum yapacak katılımcılar, diğer yöneticiler, ikram personeli, yardımcı ekipmandan sorumlu personel ile ön toplantı veya görüşme yapılmalı görevler üzerinde mutabık kalınmalıdır. Katılımcıların seçiminde ölçüt konuyla ilgisi olanlar ve bilgisi olanlardır. (Açıkalın,1995:96). Tüm katılımcıların da görüşü alınarak hazırlanmış bir gündem ile toplantının sahiplenilmesi sağlandığından başarı kaçınılmazdır. Toplantıda kontrolü kaybederek rotayı kaybetmeniz halinde hiçbir yere gidemezsiniz. İyi belirlenmiş bir toplantı konusu "Nereye gideceğim?" sorusuna cevap olurken, kurulacak etkili bir yönetim düzeni ile de başka bir yere gitmemiş oluruz. (Payne, J. ve S., 1998:31) .

Tüm bu basamakların hızlı ve etkili bir şeklide atlatılması sonucunda gelinen noktada toplantı gününde yönetici, toplantıyı kontrol altında tutabilmek için;

- Zaman yönetimine aykırı davranan katılımcılar,

- Uhuvveti bozacak miktarda ve şekilde konuşarak toplantıyı sabote edenler,

- Toplantıda diğerlerinin görüş bildirmesine fırsat vermeyerek üstün çıkmaya çalışan katılımcı(lar) (Morgan, $2006: 64$ )

- Gündemde ele alınan konunun, problemin, sorunun bir yerin(d)e takılan ya da tekraren aynı yerde dönüp duran katılımcılar (Morgan, 2006: 64;Doyle ve Stratus, 1998: 125)

- Toplantıya adapte olamamış veya ilgisiz davrananlar

- Toplantının kumandasını eline alan ve gündem dışı bir meseleye odaklanan bir grup

- Grup içinde-bağırarak, toplantıyı terk ederek ve atmosferi bozarak-kopma noktasına gelecek kadar fikir ayrılığı içinde olan üyelerin varlığı (Morgan,2006: 64 )

- $\quad$ Şakacı katılımcılar (Payne, J ve S. ,1998:57)

- Yeni fikirleri ve değişiklikleri engelleyen kişiler (Payne, J ve S. ,1998:57)

- $\quad$ Şüpheci kişiler (Doyle ve Stratus, 1998: 125) 
- Yorumcular

- $\quad$ Dedikoducular (Doyle ve Stratus, 1998: 129)

- Göze girmeye çalışanlar (Doyle ve Stratus, 1998: 133)

ile baş ederek yoluna devam etmelidir.

Toplantı yöneticisinden beklenen diğer beceriler problem çözme, kayıt tutma ve bitirme için gereken becerilerdir. Belki de sürecin en önemli ve gözden kaçan aşaması ise atılan okun hedefi vurup vurmadığını kontrol etmeden arkaya dönüp gitmek anlamına gelen sonuca ulaşılıp ulaşıımadığının denetimidir. Takip edilmeyen kararlar hiç alınmamış gibidir. Yapılan toplantının hedefine ulaşabilmesi için gereken takibin en önemli şartı olarak; gündem, toplantı tutanağı, yöneticinin notları, ek bilgiler, gelecek toplantıya sevk edilen konular (Lınkemer,1993:56) ve görevleri ile ilgili ihtiyaç duyacakları ek ve yardımcı kaynaklar toplantı sonrası tüm katılımcılara ve ilgililere gönderilmelidir. (Morgan,2006:84) Ayrıca okulun duyuru araçlarında sergilenerek kararlar takip edilebilir ve görevli(ler) üzerinde otorite sağlanabilir.

\section{METODOLOJi}

\subsection{Araştırma Modeli}

Araştırmada öğretmenlerin algılarına göre okul müdürlerinin toplantı yönetim becerilerinin 2009 yılı ile 2021 yıllarındaki yaklaşımlarının karşılaştırılması amaçlanmıştır. Bu araştırmada veri toplamak amacıyla nicel yöntemlere ilişkin anket tekniği tercih edilmiştir. Nicel araştırmalar, belirli bir problemin/problemlerin teoriler aracılığıyla sınanması, sayısal olarak ölçülmesi ve istatistiksel yöntemler aracılı̆ı̆la analiz edilmesi olarak tanımlanmaktadır (Padem, Göksu ve Konaklı, 2012: 58). Konu ile ilgili bilgilere literatür taraması ile ulaşılmıştır. Tarama modelleri bugün veya geçmişte var olan bir problemi var olduğu şekliyle irdelemeyi amaç edinen modellerdir. Araştırmaya konu durum, kişi veya nesne, içinde var olduğu şartlar altında ve olduğu gibi tanımlanmaya çalışılır (Karasar, 2007:54).

MEB okullarında yöneticilerin toplantı yönetimi tutum ve becerilerinin öğretmenler tarafından algısı içerisinde olabilecek durumlar anket ifadelerine dönüştürmüştür. Daha sonra elde edilen bulgulara dayanılarak öğretmen görüşleri betimlenmeye çalışımıştır. Anketteki ifadelere ilişkin yönetici ve öğretmen görüşlerinin cinsiyet, öğrenim durumu, kıdem değişkenlerine bağlı olarak anlamlı şekilde değişip değişmediği de test edilmeye çalışılmıştır. Bu yönüyle araştırmamız nicel bir araştırmadır.

Bu çalışmada veri toplamak amacıyla demografik bilgi formu ve toplantı yönetimi yeterliklerini belirleme ölçeği olmak üzere iki araç kullanılmıştır. Araştırmacı tarafından geliştirilen demografik bilgi formu, araştırmada yer alan katılımcıların cinsiyet, öğrenim durumu ve mesleki hizmet süresi özelliklerini içermektedir. Demografik bilgi formunun oluşturulması sürecinde literatürde konuya yönelik daha önce yapılan çalışmalar temel alınmıştır.

Okul yöneticilerinin "Toplantı Yönetimi Tutum ve Becerileri" ni ölçmeye yönelik 47 maddeden oluşan ifadelerden oluşan bir anket formu Çalışkan (2009) tarafından oluşturulmuştur. Görüşlerinin nasıl bir dağılım gösterdiğini belirlemek için anket formunda bulunan tüm maddelere verilen cevapların madde ortalamaları, standart sapmaları, boyut ortalamaları, düzeyleri ve güvenilirlilik hesaplanmış olup sonuçlar Tablo 2' de gösterilmektedir.

Boyutlar;

1. boyutta; "Toplantı Yönetim Becerileri" ne ilişkin 30,

2. boyutta; "Zaman Kontrolünü Yönetme” ye ilişkin 7,

3. boyutta; "Salon Olanaklarını Yönetme" ye ilişkin 2,

4. boyutta; "Toplantı Gündemini Yönetme" ye ilişkin 4,

5. boyutta; "Katılımcıları Yönetme" ye ilişkin 2,

6. boyutta; "Toplantı Tutanaklarını Yönetme” ye ilişkin 2 maddeden oluşmaktadır.

Anket verileri 5'li likert ölçeğe uygun olarak,

\begin{tabular}{|l|l|l|l|l|}
\hline Hiçbir Zaman (1) & Ara Sıra (2) & Kararsızım (3) & Genellikle (4) & Her Zaman (5) \\
\hline
\end{tabular}


şeklinde derecelendirilmiştir.

Tablo 1: Toplantı Yöneticiliği Tutum ve Becerilerine ilişkin Madde Ortalamaları, Standart Sapmaları, Boyut Ortalamaları, Düzeyleri

Toplantı Yöneticiliği Tutum ve Becerileri Ölçeği Maddeleri

\begin{tabular}{|c|c|c|c|c|c|c|c|c|}
\hline & \multicolumn{4}{|c|}{2009} & \multicolumn{4}{|c|}{2021} \\
\hline & $\overline{\mathbf{x}}$ & ss & $n$ & Düzey & $\overline{\mathbf{x}}$ & ss & $n$ & Düzey \\
\hline Madde 1 & 2,72 & 0,96 & 184 & Kararsızım & 3,81 & 1,14 & 243 & Genellikle \\
\hline Madde 2 & 2,61 & 0,93 & 184 & Kararsızım & 3,93 & 1,02 & 243 & Genellikle \\
\hline Madde 3 & 2,62 & 0,95 & 184 & Kararsızım & 3,35 & 1,22 & 243 & Kararsızım \\
\hline Madde 4 & 2,74 & 0,89 & 184 & Kararsızım & 3,92 & 0,99 & 243 & Genellikle \\
\hline Madde 5 & 2,61 & 0,92 & 184 & Kararsızım & 3,97 & 0,99 & 243 & Genellikle \\
\hline Madde 6 & 2,46 & 1,02 & 184 & Ara Sıra & 3,84 & 1,11 & 243 & Genellikle \\
\hline Madde 7 & 2,49 & 0,93 & 184 & Ara Sıra & 3,70 & 1,13 & 243 & Genellikle \\
\hline Madde 8 & 2,42 & 0,88 & 184 & Ara sıra & 3,51 & 1,13 & 243 & Kararsızım \\
\hline Madde 9 & 2,42 & 0,88 & 184 & Ara sıra & 3,51 & 1,13 & 243 & Kararsızım \\
\hline Madde 10 & 2,39 & 0,90 & 184 & Ara Sıra & 3,36 & 1,21 & 243 & Kararsızım \\
\hline Madde 11 & 2,99 & 0,80 & 184 & Kararsızım & 4,14 & 1,02 & 243 & Genellikle \\
\hline Madde 12 & 2,86 & 0,91 & 184 & Kararsızım & 4,04 & 1,01 & 243 & Genellikle \\
\hline Madde 13 & 2,80 & 0,94 & 184 & Kararsızım & 3,99 & 1,06 & 243 & Genellikle \\
\hline Madde 14 & 2,59 & 0,94 & 184 & Kararsızım & 3,51 & 1,19 & 243 & Genellikle \\
\hline Madde 15 & 2,64 & 0,85 & 184 & Kararsızım & 3,86 & 1,01 & 243 & Genellikle \\
\hline Madde 16 & 2,34 & 0,90 & 184 & Ara Sıra & 3,73 & 1,06 & 243 & Genellikle \\
\hline Madde 17 & 2,50 & 0,90 & 184 & Kararsızım & 3,73 & 1,03 & 243 & Genellikle \\
\hline Madde 18 & 2,50 & 0,88 & 184 & Kararsızım & 3,77 & 1,09 & 243 & Genellikle \\
\hline Madde 19 & 2,64 & 0,87 & 184 & Kararsızım & 3,78 & 1,13 & 243 & Genellikle \\
\hline Madde 20 & 2,34 & 1,01 & 184 & Ara Sıra & 3,56 & 1,16 & 243 & Genellikle \\
\hline Madde 21 & 2,66 & 0,88 & 184 & Kararsızım & 3,72 & 1,15 & 243 & Genellikle \\
\hline Madde 22 & 3,03 & 0,74 & 184 & Kararsızım & 4,12 & 0,99 & 243 & Genellikle \\
\hline Madde 23 & 2,68 & 0,85 & 184 & Kararsızım & 3,91 & 1,01 & 243 & Genellikle \\
\hline Madde 24 & 2,66 & 0,97 & 184 & Kararsızım & 3,81 & 1,07 & 243 & Genellikle \\
\hline Madde 25 & 2,64 & 1,01 & 184 & Kararsızım & 3,84 & 1,02 & 243 & Genellikle \\
\hline Madde 26 & 2,88 & 0,74 & 184 & Kararsızım & 4,17 & 0,89 & 243 & Genellikle \\
\hline Madde 27 & 2,62 & 0,84 & 184 & Kararsızım & 4,04 & 0,91 & 243 & Genellikle \\
\hline Madde 28 & 2,78 & 0,83 & 184 & Kararsızım & 4,12 & 0,93 & 243 & Genellikle \\
\hline Madde 29 & 2,81 & 0,82 & 184 & Kararsızım & 3,45 & 1,17 & 243 & Kararsızım \\
\hline Madde 30 & 2,42 & 0,89 & 184 & Ara Sıra & 4,21 & 0,88 & 243 & Genellikle \\
\hline Toplantı yönetici becerileri & 2,63 & 0,89 & 184 & Kararsızım & 3,81 & 1,06 & 243 & Genellikle \\
\hline Madde 31 & 2,99 & 0,61 & 184 & Kararsızım & 3,34 & 1,18 & 243 & Kararsızım \\
\hline Madde 32 & 2,53 & 0,92 & 184 & Kararsızım & 4,09 & 0,86 & 243 & Genellikle \\
\hline Madde 33 & 2,84 & 0,86 & 184 & Kararsızım & 4,21 & 0,88 & 243 & Genellikle \\
\hline
\end{tabular}




\begin{tabular}{ccccc|cccc} 
Madde 34 & 2,91 & 0,76 & 184 & Kararsızım & 4,05 & 0,91 & 243 & Genellikle \\
Madde 35 & 2,66 & 0,88 & 184 & Kararsııı & 3,85 & 1,13 & 243 & Genellikle \\
Madde 36 & 2,38 & 0,95 & 184 & Ara Sıra & 3,93 & 1,01 & 243 & Genellikle \\
Madde 37 & 2,54 & 0,86 & 184 & Kararsıım & 3,78 & 1,13 & 243 & Genellikle \\
\hline Zaman kontrolü & 2,69 & 0,83 & 183 & Kararsızım & 3,82 & 1,05 & 243 & Genellikle \\
\hline Madde 38 & 2,19 & 0,90 & 184 & Ara Sıra & 3,66 & 1,19 & 243 & Genellikle \\
Madde 39 & 2,16 & 0,92 & 184 & Ara Sıra & 2,67 & 1,32 & 243 & Kararsızım \\
\hline Salon olanaklarını yönetme & 2,34 & 0,88 & 184 & Ara sıra & 3,16 & 1,25 & 243 & Kararsızım \\
\hline Madde 40 & 1,82 & 0,88 & 184 & Ara Sıra & 3,26 & 1,27 & 243 & Kararsızım \\
Madde 41 & 2,07 & 1,06 & 184 & Ara Sıra & 3,95 & 1,06 & 243 & Genellikle \\
\hline Toplantı gündemini & 1,94 & 0,97 & 184 & Ara Sıra & 3,60 & 1,16 & 243 & Genellikle \\
\hline Madde 42 & 2,68 & 0,85 & 184 & Kararsızım & 2,52 & 1,42 & 243 & Kararsızım \\
Madde 43 & 1,68 & 0,89 & 184 & Ara Sıra & 3,98 & 1,14 & 243 & Genellikle \\
Madde 44 & 2,32 & 1,14 & 184 & Ara Sıra & 3,81 & 1,08 & 243 & Genellikle \\
Madde 45 & 2,36 & 0,87 & 184 & Ara Sıra & 3,88 & 1,01 & 243 & Genellikle \\
\hline Katılımıları yönetme & 2,26 & 0,93 & 184 & Ara Sıra & 3,25 & 1,28 & 243 & Kararsızım \\
\hline Madde 46 & 2,62 & 0,79 & 184 & Kararsızım & 3,38 & 1,34 & 243 & Kararsızım \\
Madde 47 & 2,41 & 0,92 & 184 & Ara Sıra & 3,14 & 1,37 & 243 & Kararsızım \\
\hline Toplantı tutanaklarını & 2,51 & 0,85 & 184 & Kararsızım & 3,26 & 1,35 & 243 & Kararsızım \\
\hline
\end{tabular}

2009 yılında toplantı yönetici becerileri boyutunda öğretmenler $(\bar{x}=2,63)$ "kararsızım” düzeyinde görüş belirtirlerken, 2021 yılında toplantı yönetici becerileri boyutunda öğretmenler $(\bar{x}=3,81)$ "Genellikle" düzeyinde görüş belirtmişlerdir. Güncel araştırmadaki öğretmenlerin, okul yöneticilerinin toplantı yöneticiliği beceri yaklaşımı daha olumludur.

2009 yılında zaman kontrolünü yönetme boyutunda öğretmenler $(\bar{x}=2,69)$ "kararsızım" düzeyinde görüş belirtirlerken, 2021 yılında zaman kontrolünü yönetme boyutunda öğretmenler $(\bar{x}=3,82)$ "Genellikle" düzeyinde görüş belirtmişlerdir. 2021 yılında araştırmaya katılan öğretmenlere göre, okul yöneticilerinin zaman kontrolünü yönetme becerileri daha önce yapılan araştırmaya göre daha olumludur sonucuna ulaşılmıştır.

2009 yılında salon olanaklarını yönetme boyutunda öğretmenler ( $\bar{x}=2,34)$ "ara sıra" düzeyinde görüş belirtirlerken, 2021 yılında salon olanaklarını yönetme boyutunda öğretmenler $(\bar{x}=3,16)$ "kararsızım" düzeyinde görüş belirtmişlerdir. Salon olanaklarını yönetme becerileri 2021 yılında araştırmaya katılan öğretmenler için, 2009 yılında araştırmaya katılan öğretmenlere göre daha olumludur.

2009 yılında toplantı gündemini yönetme boyutunda öğretmenler $(\bar{x}=1,94)$ "ara sıra" düzeyinde görüş belirtirlerken, 2021 yılında toplantı gündemini yönetme boyutunda öğretmenler $(\bar{x}=3,60)$ "genellikle" düzeyinde görüş belirtmişlerdir. Güncel araştırmadaki öğretmenlerin, okul yöneticilerinin toplantı gündemini yönetme beceri yaklaşımı daha olumludur.

2009 yılında katılımcıları yönetme boyutunda öğretmenler $(\bar{x}=2,26)$ "ara sıra" düzeyinde görüş belirtirlerken, 2021 yılında katılımcıları yönetme boyutunda öğretmenler $(\bar{x}=3,25)$ "kararsızım" düzeyinde görüş belirtmişlerdir. 2021 yılında araştırmaya katılan öğretmenlere göre, okul yöneticilerinin katılımcıları yönetme becerileri daha önce yapılan araştırmaya göre daha olumludur sonucuna ulaşılmıştır.

2009 yılında toplantı tutanaklarını yönetme boyutunda öğretmenler $(\bar{x}=2,51)$ "kararsızım" düzeyinde görüş belirtirlerken, 2021 yılında toplantı gündemini yönetme boyutunda öğretmenler $(\bar{x}=3,26)$ "kararsızım" düzeyinde görüş belirtmişlerdir. Güncel araştırmadaki öğretmenlerin, okul yöneticilerinin toplantı tutanaklarını yönetme beceri yaklaşımı daha olumludur. 


\subsection{Araştırmanın Hipotezleri}

Araştırmada demografik özelliklere göre iki hipotez, toplantı yönetim becerileri içinde beş alt hipotez olmak üzere toplamda yedi hipotez oluşturulmuştur.

H1: Öğretmenlerin 2009 yılında demografik özelliklerine göre okul yöneticilerinin toplantı yöneticiliği tutum ve beceri puanı farklılaşmaktadır.

H2: Öğretmenlerin 2021 yılında demografik özelliklerine göre okul yöneticilerinin toplantı yöneticiliği tutum ve beceri puanı farklılaşmaktadır.

H3: Okul yöneticilerinin 2009 yılındaki toplantı yönetici becerileri yaklaşımı ile 2021 yılındaki toplantı yönetici becerileri yaklaşımlarının öğretmenler tarafından algısı farklılaşmaktadır.

H3A: Okul yöneticilerinin 2009 yılındaki zaman kontrolünü yönetme yaklaşımı ile 2021 yılındaki zaman kontrolünü yönetme yaklaşımlarının öğretmenler tarafından algısı farklılaşmaktadır.

H3B: Okul yöneticilerinin 2009 yılındaki salon olanaklarını yönetme yaklaşımı ile 2021 yılındaki salon olanaklarını yönetme yaklaşımlarının öğretmenler tarafından algısı farklılaşmaktadır.

H3C: Okul yöneticilerinin 2009 yılındaki toplantı gündemini yönetme yaklaşımı ile 2021 yılındaki toplantı gündemini yönetme yaklaşımlarının öğretmenler tarafından algısı farklılaşmaktadır.

H3D: Okul yöneticilerinin 2009 yılındaki katılımcıları yönetme yaklaşımı ile 2021 yılındaki katılımcıları yönetme yaklaşımlarının öğretmenler tarafından algısı farklılaşmaktadır.

H3E: Okul yöneticilerinin 2009 yılındaki toplantı tutanaklarını yönetme ile 2021 yılındaki toplantı tutanaklarını yönetme yaklaşımlarının öğretmenler tarafından algısı farklılaşmaktadır.

\subsection{Veri Analizi ve Bulgular}

Verilerin istatistiksel analizinde SPSS (Statistical Package For Social Sciences for Windows, Release ver. 25.0) paket programından yararlanılmıştır. Bu bölümde; kullanılan testler, tanımlayıcı istatistikler (frekans analizi, betimleyici istatistikler, ortalama, standart sapma, analitik karşılaştırmalar) ve güvenirlik analizi, Bağımsız Örneklem T testi ve Anova analizi hakkında bilgi verilmektedir.

Verilerin frekans, yüzde gibi tanımlayıcı istatistiklerden faydalanılmıştır ve analitik karşılaştırmalar yapılmıştır. Kategorik verilerde, numerik verilerde de parametrik olan istatistikler kullanılmıştır. İki değişken grubu arasında anlamlı bir farklılık bulunup bulunmamasının incelenmesinde Bağımsız Örneklem T testi kullanılmıştır. İkiden fazla değişken grubunun niceliksel değişken arasında ilişki bulunup bulunmadığını incelemek için Anova Analizi uygulanmıştır (Kalaycı, 2018: 106). Araştırmada anlamlılık düzeyi 0.05 olarak baz alınmıştır. Tablolarda görülen $p$ değerinin 0.05 'ten küçük olmasıyla anlamlı bir fark olduğu, $p$ değerinin 0.05 'ten büyük olduğu durumlarda ise gurupların görüşleri arasında anlamlı bir fark olmadığı belirlenmiştir. ANOVA analizlerinde anlamlı fark bulunması durumunda bu anlamlı farkın kaynağını tespit etmek için çoklu karşılaştırma (Post Hoc) testleri kullanılmıştır. Bu testler belirlenirken; grup varyanslarının eşit olduğu varsayımı karşılandığı durumlarda çoklu karşılaştırma testlerinden Duncan, Tukey, LSD (Least Significant Difference) ve Bonferroni testlerinden biri, grup varyanslarının eşit olmadığı durumlarda ise Dunnett's C testi seçilebilir (Büyüköztürk, 2002: 48; Can, 2014: 152).

\subsection{Güvenirlik Analizi}

Güvenirlik analizinden Cronbach Alpha katsayısı testi kullanılmıştır. Verilen ifadelerde ölçeklerin ikiden fazla olduğunda ve maddelerin güvenirliğine bakılmak amacıyla Cronbach Alpha kullanılmıştır. Burada Cronbach Alpha'nın kullanılma nedeni, yapılan anketin güvenilirliğini ölçmek olduğundan, anketten elde edilen verilere uygulanan analizin, daha doğru ve gerçekçi sonuçlar ortaya çıkmasında yol gösterici bir katsayı değeri olarak görülmektedir (Şencan, 2005: 168). Cronbach Alpha değerini bulmak için SPSS 25.0 paket programı kullanılmıştır. Yapılan incelemeler sonuçlarına göre; 2021 yılı Toplantı Yöneticiliği Tutum ve Becerileri ölçeği ile ilgili yapılan güvenirlik analizi sonucunda Cronbach's Alpha değeri 0,967 (Tablo2) olarak hesaplanmıştır. 2009 yılı toplantı yöneticiliği tutum ve becerileri ölçeği Cronbach's Alpha değeri ise 0,927 'dir. İki araştırma sürecinde elde edilen sonuçlar literatüre göre oldukça yüksek güvenilirliğe sahiptirler. 
Tablo 2: Yıllara Göre Toplantı Yöneticiliği Tutum ve Becerileri Ölçeği Cronbach’s Alpha

\begin{tabular}{|l|c|}
\hline Ölçek & Cronbach's Alpha Değeri \\
\hline 2009 Yılı Toplantı Yöneticiliği Tutum ve Becerileri ölçeği & 0,927 \\
\hline 2021 Yılı Toplantı Yöneticiliği Tutum ve Becerileri ölçeği & 0,967 \\
\hline
\end{tabular}

\subsection{Katılımcılara Ait Demografik Bilgiler ve Bulgular}

Araştırmaya katılan öğretmenlerin 2009 ve 2021 yıllarındaki cinsiyet, öğrenim durumu ve mesleki hizmet süresi değişkenlerine göre dağılımlarına ilişkin bilgiler aşağıdaki Tablo 3'te verilmiştir.

Tablo 3: Araştırmada Yer Alan Katılımcıların Bazı Kişisel Özellikleri

\begin{tabular}{|c|c|c|c|c|}
\hline \multirow[b]{2}{*}{ Cinsiyet } & \multicolumn{2}{|c|}{2009} & \multicolumn{2}{|c|}{2021} \\
\hline & $\mathbf{n}$ & $\%$ & $\mathbf{n}$ & $\%$ \\
\hline Erkek & 184 & 44,0 & 99 & 40,7 \\
\hline Kadın & 234 & 56,0 & 144 & 59,3 \\
\hline Toplam & 418 & 100,0 & 243 & 100,0 \\
\hline Eğitim & $n$ & $\%$ & $\mathbf{n}$ & $\%$ \\
\hline Yüksekokul & 47 & 11,2 & 2 & ,8 \\
\hline Lisans & 349 & 83,5 & 186 & 76,5 \\
\hline Lisansüstü & 22 & 5,3 & 55 & 22,6 \\
\hline Toplam & 418 & 100,0 & 243 & 100,0 \\
\hline Hizmet süresi & $\mathbf{n}$ & $\%$ & $\mathbf{n}$ & $\%$ \\
\hline 1 ile 5 yıl arası & 202 & 48,3 & 43 & 17,7 \\
\hline 6 ile 10 yıl arası & 121 & 28,9 & 49 & 20,2 \\
\hline 11 ile 15 yıl arası & 63 & 15,1 & 51 & 21,0 \\
\hline 16 ile 20 yıl arası & 13 & 3,1 & 40 & 16,5 \\
\hline 21 ve üzeri & 19 & 4,5 & 60 & 24,7 \\
\hline Total & 418 & 100,0 & 243 & 100,0 \\
\hline
\end{tabular}

Tablo 3’te görüldüğü üzere 2009 yılında yürütülen araştırma sürecinde katılımcılar \%44 oranla erkek be \%56 oranla kadındır. 2021 yılında yürütülen araştırma sürecinde ise katılımcılar \%40,7 oranla erkek, \%59,3 oranla kadındır.

Katılımcıların eğitim durumlar incelendiğinde 2009 yılında \%11,2 oranla yüksekokul eğitim seviyesinde, \%83,5 oranla lisans eğitim seviyesinde ve $\% 5,3$ oranla lisansüstü eğitim seviyesindedir. 2021 yılında da oranlar benzerlik göstermekte olup, \%0,8 oranla yüksekokul, \%76,5 oranla lisans ve \%22,6 lisansüstü eğitim seviyesine sahiptirler.

Katılımcıların 2009 yılında \%48,3 oranla 1-5 yıl arası, \%28,9 oranla 6-10 yıl arası, \%15,1 oranla 11-15 yıl arası, \%3,1 oranla 16-20 yıl arası, \%4,5 oranla 21 yıl üzeri hizmet süresine sahip olduğu görülmektedir. 2021 yılına bakıldığında katılımcıların \%17,7 oranla 15 yıl arası, \%20,2 oranla 6-10 yıl arası, \%21,0 oranla 11-15 yıl arası, \%16,5 oranla 16-20 yıl arası ve \%24,7 oranla ise 21 yıl üzeri hizmet süresine sahip olduğu görülmektedir.

\subsection{Cinsiyete Göre Toplantı Yöneticiliği Tutum ve Becerileri Yaklaşımları T Testi ve Bulgular}

Tablo 4'te öğretmenlere göre, okul yöneticilerinin toplantı yöneticiliği tutum ve beceri yaklaşımlarına ait 6 boyutun $\mathrm{t}$ testi analiz sonuçları görülmektedir. Elde edilen sonuçlara göre, toplantı yönetici becerileri, zaman kontrolünü yönetme, salon olanaklarını yönetme, katılımcıları yönetme ve toplantı tutanaklarını yönetme boyutları cinsiyete göre istatistiksel olarak anlamlı bir farklılık göstermemektedir. 
Tablo 4: 2009 Yılı Cinsiyete göre Toplantı Yöneticiliği Tutum ve Becerileri Yaklaşımları

\begin{tabular}{|c|c|c|c|c|c|c|}
\hline & Cinsiyet & $\mathbf{n}$ & $\overline{\mathbf{x}}$ & SS & $\mathbf{t}$ & $\mathbf{P}$ \\
\hline \multirow[t]{2}{*}{ Toplantı yönetici becerileri } & Erkek & 184 & 2,56 & 0,59 & 0,297 & 0,767 \\
\hline & Kadın & 234 & 2,54 & 0,58 & & \\
\hline \multirow[t]{2}{*}{ Zaman kontrolünü yönetme } & Erkek & 184 & 2,61 & 0,61 & 0,790 & 0,430 \\
\hline & Kadın & 233 & 2,56 & 0,62 & & \\
\hline \multirow[t]{2}{*}{ Salon olanaklarını yönetme } & Erkek & 179 & 2,52 & 0,83 & $-0,801$ & 0,424 \\
\hline & Kadın & 229 & 2,59 & 0,88 & & \\
\hline \multirow{2}{*}{$\begin{array}{l}\text { Toplantı gündemini } \\
\text { yönetme }\end{array}$} & Erkek & 184 & 2,52 & 0,75 & 1,764 & $0,048 *$ \\
\hline & Kadın & 233 & 2,39 & 0,76 & & \\
\hline \multirow[t]{2}{*}{ Katılımcıları yönetme } & Erkek & 183 & 2,22 & 0,91 & 0,822 & 0,412 \\
\hline & Kadın & 229 & 2,15 & 0,88 & & \\
\hline \multirow{2}{*}{$\begin{array}{l}\text { Toplantı tutanaklarını } \\
\text { yönetme }\end{array}$} & Erkek & 170 & 2,23 & 0,92 & 0,858 & 0,391 \\
\hline & Kadın & 200 & 2,15 & 0,87 & & \\
\hline
\end{tabular}

Öğretmenlere göre okul yöneticilerinin toplantı gündemini yönetme ve becerileri, cinsiyete göre istatistiksel olarak anlamlı bir farklıı̆a sahip olduğu belirlenmiştir $(p=0,048 ; p<0,05)$. Kadın katılımcılara göre yöneticilerin toplantı gündemini yönetme oranı 2,52 'dir ve erkek katılımcılara göre ise 2,59 'dur.

Tablo 5'te 2021 yılına ait katılımcı öğretmenlerin, cinsiyete göre okul yöneticilerinin toplantı yöneticiliği tutum ve beceri yaklaşımlarına ait istatistiksel analiz sonuçlarını görmekteyiz. Elde edilen sonuçlara göre ise, kadın öğretmenler ile erkek öğretmenlerin, okul yöneticilerinin toplantı yöneticiliği tutum ve becerilerine olan algıları arasında istatistiksel olarak anlamlı bir farklılık belirlenmemiştir $(p>0,05)$.

Tablo 5: 2021 Yılı Cinsiyete göre Toplantı Yöneticiliği Tutum ve Becerileri Yaklaşımları

\begin{tabular}{|c|c|c|c|c|c|c|}
\hline & Cinsiyet & $\mathbf{n}$ & $\overline{\mathbf{x}}$ & SS & $\mathbf{t}$ & $\mathbf{P}$ \\
\hline \multirow[t]{2}{*}{ Toplantı yönetici becerileri } & Erkek & 99 & 3,76 & 0,68 & $-0,551$ & 0,582 \\
\hline & Kadın & 144 & 3,81 & 0,74 & & \\
\hline \multirow[t]{2}{*}{ Zaman kontrolünü yönetme } & Erkek & 99 & 3,89 & 0,86 & $-0,703$ & 0,483 \\
\hline & Kadın & 144 & 3,97 & 0,84 & & \\
\hline \multirow[t]{2}{*}{ Salon olanaklarını yönetme } & Erkek & 99 & 3,26 & 0,77 & 0,466 & 0,642 \\
\hline & Kadın & 144 & 3,21 & 0,87 & & \\
\hline \multirow{2}{*}{$\begin{array}{l}\text { Toplantı gündemini } \\
\text { yönetme }\end{array}$} & Erkek & 99 & 3,76 & 0,92 & 0,031 & 0,975 \\
\hline & Kadın & 144 & 3,76 & 0,94 & & \\
\hline \multirow[t]{2}{*}{ Katılımcıları yönetme } & Erkek & 99 & 3,00 & 0,95 & 0,545 & 0,586 \\
\hline & Kadın & 144 & 2,93 & 1,00 & & \\
\hline \multirow{2}{*}{$\begin{array}{l}\text { Toplantı tutanaklarını } \\
\text { yönetme }\end{array}$} & Erkek & 99 & 3,62 & 1,03 & 0,782 & 0,435 \\
\hline & Kadın & 144 & 3,51 & 1,09 & & \\
\hline
\end{tabular}

2009 yılına bakıldığında kadın öğretmenler, erkek öğretmenlere göre, okul yöneticilerinin toplantı gündemini yönetme algılarına daha olumlu yaklaşmaktadırlar. Fakat günümüzde, kadın öğretmenler ile erkek öğretmenler arasında, okul yöneticilerinin toplantı yöneticiliği tutum ve becerilerine olan algıları farklılaşmamaktadır.

\subsection{Eğitim Durumuna Göre Toplantı Yöneticiliği Tutum ve Becerileri Yaklaşımları Anova Analizi ve Bulgular}

Tablo 6'da 2009 yıındaki katılımcı öğretmenlerin, eğitim durumlarına göre okul yöneticilerinin toplantı yöneticiliği tutum ve beceri algılarına ait alt boyutların anova analizi sonuçları bulunmaktadır. Bu bağlamda, zaman kontrolünü yönetme, salon olanaklarını 
yönetme, toplantı gündemini yönetme ve katılımcıları yönetme boyutları eğitim durumlarına göre anlamlı bir farklılığa sahip değildir.

Tablo 6: 2009 Yılı Eğitim Durumuna Göre Toplantı Yöneticiliği Tutum ve Becerileri Yaklaşımları

\begin{tabular}{|c|c|c|c|c|c|c|}
\hline & Eğitim Durumu & $\mathbf{n}$ & $\overline{\mathbf{x}}$ & SS & $\mathbf{F}$ & $\mathbf{P}$ \\
\hline \multirow[t]{4}{*}{ Toplantı yönetici becerileri } & Yüksekokul & 47 & 2,65 & 0,69 & 3,635 & $0,027^{*}$ \\
\hline & Lisans & 349 & 2,56 & 0,57 & & \\
\hline & Lisansüstü & 22 & 2,25 & 0,54 & & \\
\hline & Total & 418 & 2,55 & 0,58 & & \\
\hline \multirow{4}{*}{$\begin{array}{l}\text { Zaman kontrolünü } \\
\text { yönetme }\end{array}$} & Yüksekokul & 47 & 2,71 & 0,58 & 1,187 & 0,306 \\
\hline & Lisans & 348 & 2,57 & 0,63 & & \\
\hline & Lisansüstü & 22 & 2,52 & 0,46 & & \\
\hline & Total & 417 & 2,58 & 0,62 & & \\
\hline \multirow[t]{4}{*}{ Salon olanaklarını yönetme } & Yüksekokul & 45 & 2,70 & 0,77 & 1,168 & 0,312 \\
\hline & Lisans & 341 & 2,55 & 0,88 & & \\
\hline & Lisansüstü & 22 & 2,36 & 0,63 & & \\
\hline & Total & 408 & 2,56 & 0,85 & & \\
\hline \multirow{4}{*}{$\begin{array}{l}\text { Toplantı gündemini } \\
\text { yönetme }\end{array}$} & Yüksekokul & 47 & 2,54 & 0,77 & 1,651 & 0,193 \\
\hline & Lisans & 348 & 2,46 & 0,75 & & \\
\hline & Lisansüstü & 22 & 2,19 & 0,75 & & \\
\hline & Total & 417 & 2,45 & 0,76 & & \\
\hline \multirow[t]{4}{*}{ Katılımcıları yönetme } & Yüksekokul & 46 & 2,22 & 0,86 & 0,081 & 0,922 \\
\hline & Lisans & 345 & 2,17 & 0,91 & & \\
\hline & Lisansüstü & 21 & 2,14 & 0,69 & & \\
\hline & Total & 412 & 2,18 & 0,90 & & \\
\hline \multirow{4}{*}{$\begin{array}{l}\text { Toplantı tutanaklarını } \\
\text { yönetme }\end{array}$} & Yüksekokul & 44 & 2,40 & 0,98 & 2,530 & $0,041^{*}$ \\
\hline & Lisans & 307 & 2,18 & 0,88 & & \\
\hline & Lisansüstü & 19 & 1,86 & 0,92 & & \\
\hline & Total & 370 & 2,19 & 0,90 & & \\
\hline
\end{tabular}

Okul yöneticilerinin toplantı yönetici becerileri ve toplantı tutanaklarını yönetme becerileri, katılımcıların eğitim durumuna göre istatistiksel olarak anlamlı bir farklılık göstermektedir ( $p=0,027 ; p=0,041 ; p<0,05)$.

Eğitim durumu yüksekokul olan öğretmenlerin, okul yöneticilerinin toplantı yönetici becerileri algısı 2,65'tir, eğitim durumu lisans olan öğretmenlerin, okul yöneticilerinin toplantı yönetici becerileri algısı 2,56'dır, eğitim durumu lisansüstü olan öğretmenlerin, okul yöneticilerinin toplantı yönetici becerileri algısı 2,25'tir. Bu bağlamda 2009 yılında okul yöneticilerinin toplantı yönetici becerileri algısı en olumlu olan eğitim seviyesi yüksekokuldur.

Eğitim durumu yüksekokul olan öğretmenlerin, okul yöneticilerinin toplantı tutanaklarını yönetme becerileri algısı 2,40'tır, eğitim durumu lisans olan öğretmenlerin, okul yöneticilerinin toplantı tutanaklarını yönetme becerileri algısı 2,18'dir, eğitim durumu lisansüstü olan öğretmenlerin, okul yöneticilerinin toplantı tutanaklarını yönetme becerileri algısı 2,86'dır. Bu bağlamda 2009 yılında okul yöneticilerinin toplantı tutanaklarını yönetme becerileri en olumlu olan eğitim seviyesi yüksekokuldur.

Tablo 7'de görüldüğü üzere örneklem grubunu oluşturan 2009 yılındaki okul öğretmenlerinin eğitim durumlarına göre okul yöneticilerinin toplantı yönetimi becerilerine ilişkin algılarında hangi gruplar arasında farklılaştığını belirlemek üzere yapılan Scheffe testi sonucunda, söz konusu farklılığın toplantı yönetici becerileri ve toplantı tutanaklarını yönetme alt boyutlarında, yüksekokul ile lisansüstü eğitim grupları arasında anlamlı farklılığın olduğu ve yüksekokul eğitim seviyesindekilerin daha olumlu düşündükleri sonucuna ulaşılmıştır. Diğer gruplar arasında istatistiksel olarak anlamlı bir fark yoktur. 
Tablo 7: 2009 Yılı Eğitim Durumuna Göre Scheffe Testi Sonuçları

\begin{tabular}{llllll}
\hline Bağımlı Değişkenler & & & & & \\
& (I) Öğrenim durumu & (J) Öğrenim durumu & (I-J) & SS & P \\
\hline Toplantı yönetici becerileri & Yüksekokul & Lisans &, 09564 & 0,09 & 0,57 \\
& & Lisansüstü &, $40169^{*}$ & 0,15 & 0,03 \\
\cline { 2 - 6 } & Lisans & Yüksekokul &,- 09564 & 0,09 & 0,57 \\
& & Lisansüstü &, 30605 & 0,12 & 0,05 \\
\cline { 2 - 6 } & Lisansüstü & Yüksekokul &,$- 40169^{*}$ & 0,15 & 0,03 \\
Toplantı tutanaklarını & Yüksekokul & Lisans &,- 30605 & 0,12 & 0,05 \\
yönetme & & Lisans &, 22505 & 0,14 & 0,30 \\
& & Lisansüstü &, $54067^{*}$ & 0,24 & 0,04 \\
\cline { 2 - 6 } & Lisans & Yüksekokul &,- 22505 & 0,14 & 0,30 \\
& & Lisansüstü &, 31562 & 0,21 & 0,33 \\
\cline { 2 - 6 } & Lisansüstü & Yüksekokul &,$- 54067^{*}$ & 0,24 & 0,04 \\
& & Lisans &,- 31562 & 0,21 & 0,33 \\
\hline
\end{tabular}

Tablo 8'de günümüzdeki katılımcı öğretmenlerin görüşlerine göre, eğitim durumlarına göre okul yöneticilerinin toplantı yöneticiliği tutum ve beceri algılarına ait alt boyutların anova analizi sonuçlarını görmekteyiz. Sonuç olarak, toplantı yönetici becerileri, zaman kontrolünü yönetme, toplantı gündemini yönetme, katılımcıları yönetme ve toplantı tutanaklarını yönetme boyutları eğitim durumlarına göre anlamlı bir farklılığa sahip değildir.

Tablo 8: 2021 Yılı Eğitim Durumuna Göre Toplantı Yöneticiliği Tutum ve Becerileri Yaklaşımları

\begin{tabular}{|c|c|c|c|c|c|c|}
\hline & Eğitim Durumu & $\mathbf{n}$ & $\overline{\mathbf{x}}$ & SS & $\mathbf{F}$ & $\mathbf{P}$ \\
\hline \multirow[t]{4}{*}{ Toplantı yönetici becerileri } & Yüksekokul & 2 & 4,60 & 0,32 & 1,304 & 0,273 \\
\hline & Lisans & 186 & 3,78 & 0,74 & & \\
\hline & Lisansüstü & 55 & 3,82 & 0,62 & & \\
\hline & Total & 243 & 3,79 & 0,72 & & \\
\hline \multirow{4}{*}{$\begin{array}{l}\text { Zaman kontrolünü } \\
\text { yönetme }\end{array}$} & Yüksekokul & 2 & 4,64 & 0,50 & 1,297 & 0,275 \\
\hline & Lisans & 186 & 3,96 & 0,88 & & \\
\hline & Lisansüstü & 55 & 3,82 & 0,73 & & \\
\hline & Total & 243 & 3,93 & 0,85 & & \\
\hline \multirow[t]{4}{*}{ Salon olanaklarını yönetme } & Yüksekokul & 2 & 3,75 & 1,06 & 3,283 & $0,039 *$ \\
\hline & Lisans & 186 & 3,15 & 0,86 & & \\
\hline & Lisansüstü & 55 & 3,46 & 0,67 & & \\
\hline & Total & 243 & 3,23 & 0,83 & & \\
\hline \multirow{4}{*}{$\begin{array}{l}\text { Toplantı gündemini } \\
\text { yönetme }\end{array}$} & Yüksekokul & 2 & 4,62 & 0,53 & 0,849 & 0,429 \\
\hline & Lisans & 186 & 3,75 & 0,96 & & \\
\hline & Lisansüstü & 55 & 3,76 & 0,84 & & \\
\hline & Total & 243 & 3,76 & 0,93 & & \\
\hline \multirow[t]{4}{*}{ Katılımcıları yönetme } & Yüksekokul & 2 & 3,50 & 0,70 & 1,012 & 0,365 \\
\hline & Lisans & 186 & 2,91 & 0,98 & & \\
\hline & Lisansüstü & 55 & 3,10 & 1,05 & & \\
\hline & Total & 243 & 2,96 & 0,99 & & \\
\hline \multirow{4}{*}{$\begin{array}{l}\text { Toplantı tutanaklarını } \\
\text { yönetme }\end{array}$} & Yüksekokul & 2 & 3,75 & 1,06 & 0,086 & 0,918 \\
\hline & Lisans & 186 & 3,57 & 1,10 & & \\
\hline & Lisansüstü & 55 & 3,51 & 0,95 & & \\
\hline & Total & 243 & 3,56 & 1,06 & & \\
\hline
\end{tabular}


2021 yılındaki araştırma sonuçlarına göre, okul yöneticilerinin salon olanaklarını yönetme becerileri, katılımcıların eğitim durumuna göre istatistiksel olarak anlamlı bir farklılık göstermektedir $(p=0,039 ; p<0,05)$.

Eğitim durumu yüksekokul olan öğretmenlerin, okul yöneticilerinin salon olanaklarını yönetme becerileri algıSı 3,75'tir, eğitim durumu lisans olan öğretmenlerin, okul yöneticilerinin salon olanaklarını yönetme becerileri algısı 3,15'tir, eğitim durumu lisansüstü olan öğretmenlerin, okul yöneticilerinin salon olanaklarını yönetme becerileri algısı 3,46'dır. Bu bağlamda 2021 yılında okul yöneticilerinin toplantı yönetici becerileri algısı en olumlu olan eğitim seviyesi yüksekokuldur.

Tablo 9'da görüldüğü üzere örneklem grubunu oluşturan 2021 yılındaki okul öğretmenlerinin eğitim durumlarına göre okul yöneticilerinin toplantı yönetimi becerilerine ilişkin algılarında hangi gruplar arasında farklılaştığını belirlemek üzere yapılan LSD testi sonucunda, söz konusu farklılığın salon olanaklarını yönetme alt boyutunda, lisans ile lisansüstü eğitim grupları arasında anlamlı farklılığın olduğu ve lisansüstü eğitim seviyesindekilerin daha olumlu düşündükleri sonucuna ulaşılmıştır. Diğer gruplar arasında istatistiksel olarak anlamlı bir fark yoktur.

Tablo 9: 2021 Yılı Eğitim Durumuna Göre LSD Testi Sonuçları

\begin{tabular}{llllll}
\hline Bağımlı değişken & (I) Öğrenim durumu & (J) Öğrenim durumu & (I-J) & SS & P \\
\hline Salon olanaklarını & Yüksekokul & Lisans &, 59140 & 0,58 & 0,31 \\
yönetme & Lisansüstü &, 28636 & 0,59 & 0,63 \\
\cline { 2 - 6 } & Lisans & Yüksekokul &,- 59140 & 0,58 & 0,31 \\
& & Lisansüstü &,$- 30503^{*}$ & 0,12 & 0,01 \\
\cline { 2 - 6 } & Lisansüstü & Yüksekokul &,- 28636 & 0,59 & 0,63 \\
& & Lisans &, $30503^{*}$ & 0,12 & 0,01 \\
\hline
\end{tabular}

\subsection{Hizmet Süresine Göre Toplantı Yöneticiliği Tutum ve Becerileri Yaklaşımları Anova Analizi ve Bulgular}

Tablo 10'da 2009 yılındaki katılımcı öğretmenlerin, mesleki hizmet sürelerine göre okul yöneticilerinin toplantı yöneticiliği tutum ve beceri algılarına ait alt boyutların anova analizi sonuçları bulunmaktadır. Sonuç olarak, toplantı yönetim becerileri, salon olanaklarını yönetme, toplantı gündemini yönetme, katılımcıları yönetme ve toplantı tutanaklarını yönetme boyutları mesleki hizmet sürelerine göre anlamlı bir farklılığa sahip değildir.

Tablo 10: 2009 Yılı Hizmet Süresine Göre Toplantı Yöneticiliği Tutum ve Becerileri Yaklaşımları

\begin{tabular}{|c|c|c|c|c|c|c|}
\hline & Hizmet süresi & $\mathbf{n}$ & $\overline{\mathbf{x}}$ & SS & $\mathbf{F}$ & $\mathbf{P}$ \\
\hline \multirow[t]{6}{*}{ Toplantı yönetici becerileri } & 1 ile 5 yıl arası & 202 & 2,50 & 0,56 & 1,545 & 0,188 \\
\hline & 6 ile 10 yıl arası & 121 & 2,56 & 0,55 & & \\
\hline & 11 ile 15 yıl arası & 63 & 2,65 & 0,64 & & \\
\hline & 16 ile 20 yıl arası & 13 & 2,82 & 0,72 & & \\
\hline & 21 ve üzeri & 19 & 2,50 & 0,72 & & \\
\hline & Total & 418 & 2,55 & 0,58 & & \\
\hline \multirow{6}{*}{$\begin{array}{l}\text { Zaman kontrolünü } \\
\text { yönetme }\end{array}$} & 1 ile 5 yıl arası & 202 & 2,50 & 0,61 & 2,412 & $0,049 *$ \\
\hline & 6 ile 10 yıl arası & 121 & 2,58 & 0,59 & & \\
\hline & 11 ile 15 yıl arası & 62 & 2,74 & 0,60 & & \\
\hline & 16 ile 20 yıl arası & 13 & 2,76 & 0,78 & & \\
\hline & 21 ve üzeri & 19 & 2,75 & 0,70 & & \\
\hline & Total & 417 & 2,58 & 0,62 & & \\
\hline \multirow{7}{*}{$\begin{array}{l}\text { Salon olanaklarını } \\
\text { yönetme }\end{array}$} & 1 ile 5 yıl arası & 197 & 2,53 & 0,88 & 0,554 & 0,696 \\
\hline & 6 ile $10 \mathrm{yıl}$ arası & 118 & 2,61 & 0,80 & & \\
\hline & 11 ile 15 yıl arası & 61 & 2,64 & 0,90 & & \\
\hline & 16 ile 20 yıl arası & 13 & 2,50 & 0,93 & & \\
\hline & 21 ve üzeri & 19 & 2,36 & 0,74 & & \\
\hline & Total & 408 & 2,56 & 0,85 & & \\
\hline & 1 ile 5 yıl arası & 202 & 2,40 & 0,77 & 1,315 & 0,264 \\
\hline
\end{tabular}




\begin{tabular}{|c|c|c|c|c|c|c|}
\hline \multirow{6}{*}{$\begin{array}{l}\text { Toplantı gündemini } \\
\text { yönetme }\end{array}$} & \multirow[b]{2}{*}{6 ile 10 yıl arası } & \multirow[b]{2}{*}{120} & \multirow[b]{2}{*}{2,42} & \multirow[b]{2}{*}{0,75} & & \\
\hline & & & & & & \\
\hline & 11 ile 15 yıl arası & 63 & 2,64 & 0,70 & & \\
\hline & 16 ile 20 yıl arası & 13 & 2,59 & 0,90 & & \\
\hline & 21 ve üzeri & 19 & 2,46 & 0,74 & & \\
\hline & Total & 417 & 2,45 & 0,76 & & \\
\hline \multirow[t]{6}{*}{ Katılımcıları yönetme } & 1 ile 5 yıl arası & 199 & 2,18 & 0,87 & \multirow[t]{6}{*}{0,866} & \multirow[t]{6}{*}{0,484} \\
\hline & 6 ile 10 yıl arası & 119 & 2,16 & 0,91 & & \\
\hline & 11 ile 15 yıl arası & 63 & 2,11 & 0,91 & & \\
\hline & 16 ile 20 yıl arası & 13 & 2,61 & 1,13 & & \\
\hline & 21 ve üzeri & 18 & 2,22 & 0,86 & & \\
\hline & Total & 412 & 2,18 & 0,90 & & \\
\hline \multirow{6}{*}{$\begin{array}{l}\text { Toplantı tutanaklarını } \\
\text { yönetme }\end{array}$} & 1 ile 5 yıl arası & 177 & 2,16 & 0,84 & \multirow[t]{6}{*}{1,652} & \multirow[t]{6}{*}{0,161} \\
\hline & 6 ile 10 yıl arası & 107 & 2,10 & 0,96 & & \\
\hline & 11 ile 15 yıl arası & 58 & 2,43 & 0,90 & & \\
\hline & 16 ile 20 yıl arası & 12 & 2,45 & 0,98 & & \\
\hline & 21 ve üzeri & 16 & 2,06 & 0,98 & & \\
\hline & Total & 370 & 2,19 & 0,90 & & \\
\hline
\end{tabular}

Okul yöneticilerinin zaman kontrolünü yönetme becerileri, katılımcıların hizmet süresine göre istatistiksel olarak anlamlı bir farklılık göstermektedir $(p=0,049 ; p<0,05)$.

Mesleki hizmet süresi 1 ile 5 yıl arası olan öğretmenlerin, okul yöneticilerinin zaman kontrolünü yönetme becerileri algısı 2,50'dir, mesleki hizmet süresi 6 ile 10 yıl arası olan öğretmenlerin, okul yöneticilerinin zaman kontrolünü yönetme becerileri algısı 2,58'dir, mesleki hizmet süresi 11 ile 15 yıl arası olan öğretmenlerin, okul yöneticilerinin zaman kontrolünü yönetme becerileri algısı 2,74'tür, mesleki hizmet süresi 16 ile 20 yıl arası olan öğretmenlerin, okul yöneticilerinin zaman kontrolünü yönetme becerileri algısı 2,76'dır ve mesleki hizmet süresi 21 yıl üzeri olan öğretmenlerin, okul yöneticilerinin zaman kontrolünü yönetme becerileri algısı 2,75'tir. Bu bağlamda 2009 yılında okul yöneticilerinin zaman kontrolünü yönetme becerileri algısı en olumlu olanlar 11 yıldan fazla süredir çalışanlardır.

Tablo 11: 2009 Yılı Mesleki Hizmet Süresine Göre LSD Testi Sonuçları

\begin{tabular}{|c|c|c|c|c|c|}
\hline & (I) Mesleki hizmet süresi & (J) Mesleki hizmet süresi & $(I-J)$ & SS & $\mathbf{P}$ \\
\hline Zaman Kontrolünü & 1 ile 5 yıl arası & 6 ile 10 yıl arası &,- 07693 & 0,07 & 0,27 \\
\hline \multirow[t]{19}{*}{ Yönetme } & & 11 ile 15 yıl arası &,$- 23385^{*}$ & 0,08 & 0,00 \\
\hline & & 16 ile 20 yıl arası &,- 25351 & 0,17 & 0,15 \\
\hline & & 21 ve üzeri &,- 24627 & 0,14 & 0,09 \\
\hline & 6 ile 10 yıl arası & 1 ile 5 yıl arası & 07693 & 0,07 & 0,27 \\
\hline & & 11 ile 15 yıl arası &,- 15692 & 0,09 & 0,10 \\
\hline & & 16 ile 20 yıl arası &,- 17659 & 0,18 & 0,32 \\
\hline & & 21 ve üzeri &,- 16934 & 0,15 & 0,26 \\
\hline & 11 ile 15 yıl arası & 1 ile 5 yıl arası &, $23385^{*}$ & 0,08 & 0,00 \\
\hline & & 6 ile 10 yıl arası & ,15692 & 0,09 & 0,10 \\
\hline & & 16 ile 20 yıl arası &,- 01967 & 0,18 & 0,91 \\
\hline & & 21 ve üzeri &,- 01242 & 0,16 & 0,93 \\
\hline & 16 ile 20 yıl arası & 1 ile 5 yıl arası & ,25351 & 0,17 & 0,15 \\
\hline & & 6 ile 10 yıl arası & 17659 & 0,18 & 0,32 \\
\hline & & 11 ile 15 yıl arası & ,01967 & 0,18 & 0,91 \\
\hline & & 21 ve üzeri & ,00725 & 0,22 & 0,97 \\
\hline & 21 ve üzeri & 1 ile 5 yıl arası & 24627 & 0,14 & 0,09 \\
\hline & & 6 ile 10 yıl arası & 16934 & 0,15 & 0,26 \\
\hline & & 11 ile 15 yıl arası & ,01242 & 0,16 & 0,93 \\
\hline & & 16 ile 20 yıl arası &,- 00725 & 0,22 & 0,97 \\
\hline
\end{tabular}


2009 yılındaki okul öğretmenlerinin mesleki hizmet süresine göre okul yöneticilerinin toplantı yönetim becerilerine ilişkin algılarında hangi gruplar arasında farklılaştığını belirlemek üzere LSD testi uygulanmıştır ve sonuçlar Tablo $11^{\prime}$ de gösterilmektedir. Sonuçlara göre farklılığın zaman kontrolünü yönetme alt boyutunda, mesleki hizmet süresi 1 ile 5 yıl arası olan gruplar ile mesleki hizmet süresi 11 ile 15 yıl arası olan grupları arasında anlamlı farklıığın olduğu ve mesleki hizmet süresi 11 ile 15 yıl arası olanların daha olumlu düşündükleri sonucuna ulaşılmıştır. Diğer gruplar arasında istatistiksel olarak anlamlı bir fark yoktur.

Tablo 12: 2021 Yılı Hizmet Süresine Göre Toplantı Yöneticiliği Tutum ve Becerileri Yaklaşımları

\begin{tabular}{|c|c|c|c|c|c|c|}
\hline & Hizmet süresi & $\mathbf{n}$ & $\overline{\mathbf{x}}$ & SS & $\mathbf{F}$ & $\mathbf{P}$ \\
\hline \multirow[t]{6}{*}{ Toplantı yönetici becerileri } & 1 ile 5 yıl arası & 43 & 4,00 & 0,63 & 2,090 & $0,043^{*}$ \\
\hline & 6 ile 10 yıl arası & 49 & 3,58 & 0,85 & & \\
\hline & 11 ile 15 yıl arası & 51 & 3,86 & 0,65 & & \\
\hline & 16 ile 20 yıl arası & 40 & 3,78 & 0,67 & & \\
\hline & 21 ve üzeri & 60 & 3,77 & 0,71 & & \\
\hline & Total & 243 & 3,79 & 0,72 & & \\
\hline \multirow{6}{*}{$\begin{array}{l}\text { Zaman kontrolünü } \\
\text { yönetme }\end{array}$} & 1 ile 5 yıl arası & 43 & 4,18 & 0,70 & 2,174 & $0,033^{*}$ \\
\hline & 6 ile 10 yıl arası & 49 & 3,70 & 0,84 & & \\
\hline & 11 ile 15 yıl arası & 51 & 3,84 & 0,87 & & \\
\hline & 16 ile 20 yıl arası & 40 & 3,97 & 0,92 & & \\
\hline & 21 ve üzeri & 60 & 4,01 & 0,86 & & \\
\hline & Total & 243 & 3,93 & 0,85 & & \\
\hline \multirow{6}{*}{$\begin{array}{l}\text { Salon olanaklarını } \\
\text { yönetme }\end{array}$} & 1 ile 5 yıl arası & 43 & 3,17 & 1,00 & 0,536 & 0,710 \\
\hline & 6 ile 10 yıl arası & 49 & 3,22 & 0,86 & & \\
\hline & 11 ile 15 yıl arası & 51 & 3,35 & 0,85 & & \\
\hline & 16 ile 20 yıl arası & 40 & 3,11 & 0,70 & & \\
\hline & 21 ve üzeri & 60 & 3,25 & 0,75 & & \\
\hline & Total & 243 & 3,23 & 0,83 & & \\
\hline \multirow{6}{*}{$\begin{array}{l}\text { Toplantı gündemini } \\
\text { yönetme }\end{array}$} & 1 ile 5 yıl arası & 43 & 3,87 & 0,92 & 1,909 & 0,110 \\
\hline & 6 ile 10 yıl arası & 49 & 3,50 & 0,96 & & \\
\hline & 11 ile 15 yıl arası & 51 & 3,66 & 0,91 & & \\
\hline & 16 ile 20 yıl arası & 40 & 3,84 & 0,90 & & \\
\hline & 21 ve üzeri & 60 & 3,94 & 0,92 & & \\
\hline & Total & 243 & 3,76 & 0,93 & & \\
\hline \multirow[t]{6}{*}{ Katılımcıları yönetme } & 1 ile 5 yıl arası & 43 & 2,97 & 0,98 & 0,796 & 0,529 \\
\hline & 6 ile 10 yıl arası & 49 & 2,87 & 1,04 & & \\
\hline & 11 ile 15 yıl arası & 51 & 3,11 & 1,04 & & \\
\hline & 16 ile 20 yıl arası & 40 & 2,77 & 0,90 & & \\
\hline & 21 ve üzeri & 60 & 3,01 & 0,99 & & \\
\hline & Total & 243 & 2,96 & 0,99 & & \\
\hline \multirow{6}{*}{$\begin{array}{l}\text { Toplantı tutanaklarını } \\
\text { yönetme }\end{array}$} & 1 ile 5 yıl arası & 43 & 3,68 & 1,15 & 0,773 & 0,544 \\
\hline & 6 ile 10 yıl arası & 49 & 3,37 & 1,18 & & \\
\hline & 11 ile 15 yıl arası & 51 & 3,51 & 0,95 & & \\
\hline & 16 ile 20 yıl arası & 40 & 3,51 & 1,02 & & \\
\hline & 21 ve üzeri & 60 & 3,69 & 1,02 & & \\
\hline & Total & 243 & 3,56 & 1,06 & & \\
\hline
\end{tabular}

2021 yılındaki katılımcı öğretmenlerin, mesleki hizmet sürelerine göre okul yöneticilerinin toplantı yöneticiliği tutum ve beceri algılarına ait boyutların anova analizi sonuçları Tablo 12'de görülmektedir. Salon olanaklarını yönetme, toplantı gündemini 
yönetme, katılımcıları yönetme ve toplantı tutanaklarını yönetme boyutları mesleki hizmet sürelerine göre anlamlı bir farklılığa sahip değildir.

Okul yöneticilerinin toplantı yönetici becerileri ve zaman kontrolünü yönetme becerilerine göre istatistiksel olarak anlamlı bir farklılık göstermektedir ( $p=0,043 ; p<0,033 ; p<0,05)$.

Mesleki hizmet süresi 1 ile 5 yıl arası olan öğretmenlerin, okul yöneticilerinin zaman kontrolünü yönetme becerileri algısı 4,00'dür, mesleki hizmet süresi 6 ile 10 yıl arası olan öğretmenlerin, okul yöneticilerinin zaman kontrolünü yönetme becerileri algısı 3,58'dir, mesleki hizmet süresi 11 ile 15 yıl arası olan öğretmenlerin, okul yöneticilerinin zaman kontrolünü yönetme becerileri algısı 3,86'dır, mesleki hizmet süresi 16 ile 20 yıl arası olan öğretmenlerin, okul yöneticilerinin zaman kontrolünü yönetme becerileri algısı 3,78'dir ve mesleki hizmet süresi 21 yıl üzeri olan öğretmenlerin, okul yöneticilerinin zaman kontrolünü yönetme becerileri algısı 3,77'dir. Bu bağlamda 2021 yılında okul yöneticilerinin zaman kontrolünü yönetme becerileri algısı en olumlu olanlar 1 ile 5 yıl arası süredir çalışanlardır.

Mesleki hizmet süresi 1 ile 5 yıl arası olan öğretmenlerin, okul yöneticilerinin toplantı yönetme becerileri algısı 4,18'dir, mesleki hizmet süresi 6 ile 10 yıl arası olan öğretmenlerin, okul yöneticilerinin toplantı yönetme becerileri algısı 3,70'dir, mesleki hizmet süresi 11 ile 15 yıl arası olan öğretmenlerin, okul yöneticilerinin toplantı yönetme becerileri algısı 3,84'tür, mesleki hizmet süresi 16 ile 20 yıl arası olan öğretmenlerin, okul yöneticilerinin toplantı yönetme becerileri algısı 3,97'dir ve mesleki hizmet süresi 21 yıl üzeri olan öğretmenlerin, okul yöneticilerinin toplantı yönetme becerileri algısı 4,01'tir. Bu bağlamda 2021 yılında okul yöneticilerinin toplantı yönetme becerileri algısı en olumlu olanlar 1 ile 5 yıl arası süredir çalışanlardır.

Tablo 13: 2021 Yılı Mesleki Hizmet Süresine Göre LSD Testi Sonuçları

\begin{tabular}{|c|c|c|c|c|c|}
\hline Bağımlı Değişkenler & (I) hizmet süresi & (J) hizmet süresi & (I-J) & SS & $\mathbf{P}$ \\
\hline \multirow{20}{*}{$\begin{array}{l}\text { Toplantı yönetici } \\
\text { becerileri }\end{array}$} & \multirow[t]{4}{*}{1 ile 5 yıl arası } & 6 ile 10 yıl arası & ,41554* & 14920 &, 006 \\
\hline & & 11 ile 15 yıl arası & 13733 & 14783 & ,354 \\
\hline & & 16 ile 20 yıl arası & 22048 & 15685 & 161 \\
\hline & & 21 ve üzeri & ,23076 & 14267 & 107 \\
\hline & \multirow[t]{4}{*}{6 ile 10 yıl arası } & 1 ile 5 yıl arası &,$- 41554^{*}$ & 14920 & ,006 \\
\hline & & 11 ile 15 yıl arası &,- 27820 & 14283 & ,053 \\
\hline & & 16 ile 20 yıl arası &,- 19505 & 15215 & 201 \\
\hline & & 21 ve üzeri &,- 18477 & 13748 & , 180 \\
\hline & \multirow[t]{4}{*}{11 ile 15 yıl arası } & 1 ile 5 yıl arası &,- 13733 & 14783 & ,354 \\
\hline & & 6 ile 10 yıl arası & ,27820 & 14283 & ,053 \\
\hline & & 16 ile 20 yıl arası & ,08315 & 15081 & ,582 \\
\hline & & 21 ve üzeri & ,09343 & ,13599 & ,493 \\
\hline & \multirow[t]{4}{*}{16 ile 20 yıl arası } & 1 ile 5 yıl arası &,- 22048 & 15685 & 161 \\
\hline & & 6 ile 10 yıl arası & 19505 & 15215 & 201 \\
\hline & & 11 ile 15 yıl arası &,- 08315 & 15081 & ,582 \\
\hline & & 21 ve üzeri & ,01028 & ,14575 & ,944 \\
\hline & \multirow[t]{4}{*}{21 ve üzeri } & 1 ile 5 yıl arası &,- 23076 & 14267 & 107 \\
\hline & & 6 ile 10 yıl arası & 18477 & 13748 & 180 \\
\hline & & 11 ile 15 yıl arası &,- 09343 & 13599 & ,493 \\
\hline & & 16 ile 20 yıl arası &,- 01028 & 14575 & ,944 \\
\hline \multirow{10}{*}{$\begin{array}{l}\text { Zaman kontrolünü } \\
\text { yönetme }\end{array}$} & \multirow[t]{4}{*}{1 ile 5 yıl arası } & 6 ile 10 yıl arası & ,48342* & 17686 & 007 \\
\hline & & 11 ile 15 yıl arası & ,34571* & 17523 & 050 \\
\hline & & 16 ile 20 yıl arası & 21105 & 18593 & ,257 \\
\hline & & 21 ve üzeri &, 17414 & ,16911 & ,304 \\
\hline & \multirow[t]{4}{*}{6 ile 10 yıl arası } & 1 ile 5 yıl arası &,$- 48342^{*}$ & 17686 & 007 \\
\hline & & 11 ile 15 yıl arası &,- 13771 & 16931 & ,417 \\
\hline & & 16 ile 20 yıl arası &,- 27238 & 18036 & 132 \\
\hline & & 21 ve üzeri &,- 30928 & ,16297 &, 059 \\
\hline & \multirow[t]{2}{*}{11 ile 15 yıl arası } & 1 ile 5 yıl arası &,$- 34571^{*}$ & 17523 &, 050 \\
\hline & & 6 ile 10 yıl arası & 13771 & 16931 & ,417 \\
\hline
\end{tabular}




\begin{tabular}{lllll} 
& 16 ile 20 yıl arası &,- 13466 &, 17876 &, 452 \\
& 21 ve üzeri &,- 17157 &, 16120 &, 288 \\
\hline 16 ile 20 yıl arası & 1 ile 5 yıl arası &,- 21105 &, 18593 &, 257 \\
& 6 ile 10 yıl arası &, 27238 &, 18036 &, 132 \\
& 11 ile 15 yıl arası &, 13466 &, 17876 &, 452 \\
& 21 ve üzeri &,- 03690 &, 17277 &, 831 \\
\hline 21 ve üzeri & 1 ile 5 yıl arası &,- 17414 &, 16911 &, 304 \\
& 6 ile 10 yıl arası &, 30928 &, 16297 &, 059 \\
& 11 ile 15 yıl arası &, 17157 &, 16120 &, 288 \\
& 16 ile 20 yıl arası &, 03690 &, 17277 &, 831 \\
\hline
\end{tabular}

2021 yılındaki okul öğretmenlerinin mesleki hizmet süresine göre okul yöneticilerinin toplantı yönetim becerilerine ilişkin algılarında hangi gruplar arasında farklılaştığını belirlemek üzere LSD testi uygulanmıştır ve sonuçlar Tablo 13'de gösterilmektedir. Sonuçlara göre farklılığın toplantı yönetici becerileri alt boyutunda, mesleki hizmet süresi 1 ile 5 yıl arası olan gruplar ile mesleki hizmet süresi 6 ile 11 yıl arası olan grupları arasında anlamlı farklılığın olduğu ve mesleki hizmet süresi 1 ile 5 yıl arası olanların daha olumlu düşündükleri sonucuna ulaşılmıştır. Diğer gruplar arasında istatistiksel olarak anlamlı bir fark yoktur.

Diğer bir sonuca göre farklılığın zaman kontrolünü yönetme alt boyutunda, mesleki hizmet süresi 1 ile 5 yıl arası olan gruplar ile mesleki hizmet süresi 6 ile 11 yıl arası olan grupları arasında ve mesleki hizmet süresi 1 ile 5 yıl arası olan gruplar ile mesleki hizmet süresi 11 ile 15 yıl arası olan grupları arasında anlamlı farklılığın olduğu belirlenmiştir. Mesleki hizmet süresi 1 ile 5 yıl arası olanların, 6 ile 11 yıl arası olanlara ve 11 ile 15 yıl arası olanlara göre daha olumlu düşündükleri sonucuna ulaşılmıştır. Diğer gruplar arasında istatistiksel olarak anlamlı bir fark yoktur.

\subsection{Yıllara Göre Toplantı Yöneticiliği Tutum ve Becerileri Yaklaşımları t Testi ve Bulgular}

Yıllara göre toplantı yöneticiliği tutum ve beceri yaklaşımları bağımsız örneklem t testi ile incelenmiş olup elde edilen sonuçlar Tablo 14'te verilmektedir. Öğretmenlere göre, okul yöneticilerinin toplantı yönetici becerileri, yıllara göre istatistiksel olarak anlamlı bir farklılığa sahiptir $(p=0,00 ; p<0,05)$. Öğretmenlerin 2009 yılındaki toplantı yönetici becerileri ortalaması 2,55 ve 2021 yılındaki toplantı yönetici becerileri ortalaması 3,79'dur. Bu bağlamda; araştırmaya 2021 yılında katılan öğretmenler, okul yönetiminin toplantı yönetim becerilerinin 2009 yılına göre daha olumlu olduğunu düşünmektedirler.

Tablo 14: Yıllara Göre Toplantı Yöneticiliği Tutum ve Becerileri Yaklaşımı

\begin{tabular}{|c|c|c|c|c|c|c|}
\hline & YII & $\mathbf{n}$ & $\overline{\mathbf{x}}$ & SS & $\mathbf{t}$ & $\mathbf{P}$ \\
\hline \multirow[t]{2}{*}{ Toplantı yönetici becerileri } & 2009 & 418 & 2,55 & 0,58 & $-24,109$ & $0,000^{*}$ \\
\hline & 2021 & 243 & 3,79 & 0,72 & & \\
\hline \multirow[t]{2}{*}{ Zaman kontrolünü yönetme } & 2009 & 417 & 2,58 & 0,62 & $-23,856$ & $0,000^{*}$ \\
\hline & 2021 & 243 & 3,93 & 0,85 & & \\
\hline \multirow[t]{2}{*}{ Salon olanaklarını yönetme } & 2009 & 408 & 2,56 & 0,85 & $-9,704$ & $0,000^{*}$ \\
\hline & 2021 & 243 & 3,23 & 0,83 & & \\
\hline \multirow[t]{2}{*}{ Toplantı gündemini yönetme } & 2009 & 417 & 2,45 & 0,76 & $-19,556$ & $0,000^{*}$ \\
\hline & 2021 & 243 & 3,76 & 0,93 & & \\
\hline \multirow[t]{2}{*}{ Katılımcıları yönetme } & 2009 & 412 & 2,18 & 0,90 & $-10,290$ & $0,000^{*}$ \\
\hline & 2021 & 243 & 2,96 & 0,99 & & \\
\hline \multirow{2}{*}{$\begin{array}{l}\text { Toplantı tutanaklarını } \\
\text { yönetme }\end{array}$} & 2009 & 370 & 2,19 & 0,90 & $-17,067$ & $0,000^{*}$ \\
\hline & 2021 & 243 & 3,56 & 1,06 & & \\
\hline
\end{tabular}

Öğretmenlere göre, okul yöneticilerinin zaman kontrolü becerileri, yıllara göre istatistiksel olarak anlamlı bir farklılığa sahiptir $(p=0,00 ; p<0,05)$. Öğretmenlerin 2009 yılındaki zaman kontrolü becerileri ortalaması 2,58 ve 2021 yılındaki zaman yönetimi becerileri ortalaması 3,93'tür. Bu bağlamda; araştırmaya 2021 yılında katılan öğretmenler, okul yönetiminin zaman yönetimi becerilerinin 2009 yılına göre daha olumlu olduğunu düşünmektedirler.

Öğretmenlere göre, okul yöneticilerinin salon olanaklarını yönetme becerileri, yıllara göre istatistiksel olarak anlamlı bir farklılığa sahiptir ( $p=0,00 ; p<0,05$ ). Öğretmenlerin 2009 yılındaki salon olanaklarını yönetme becerileri ortalaması 2,56 ve 2021 yılındaki salon olanaklarını yönetme becerileri ortalaması 3,23’tür. Bu bağlamda; araştırmaya 2021 yılında katılan öğretmenler, okul yönetiminin salon olanaklarını yönetme becerilerinin 2009 yılına göre daha olumlu olduğunu düşünmektedirler. 
Öğretmenlere göre, okul yöneticilerinin toplantı gündemini yönetme becerileri, yıllara göre istatistiksel olarak anlamlı bir farklılı̆̆a sahiptir ( $p=0,00 ; p<0,05)$. Öğretmenlerin 2009 yılındaki toplantı gündemini yönetme becerileri ortalaması 2,45 ve 2021 yılındaki toplantı gündemini yönetme becerileri ortalaması 3,76'dır. Bu bağlamda; araştırmaya 2021 yılında katılan öğretmenler, okul yönetiminin toplantı gündemini yönetme becerilerinin 2009 yılına göre daha olumlu olduğunu düşünmektedirler.

Öğretmenlere göre, okul yöneticilerinin katılımcıları yönetme becerileri, yıllara göre istatistiksel olarak anlamlı bir farklılığa sahiptir $(p=0,00 ; p<0,05)$. Öğretmenlerin 2009 yılındaki katılımcıları yönetme becerileri ortalaması 2,18 ve 2021 yılındaki katılımcıları yönetme becerileri ortalaması 2,96'dır. Bu bağlamda; araştırmaya 2021 yılında katılan öğretmenler, okul yönetiminin katılımcıları yönetme becerilerinin 2009 yılına göre daha olumlu olduğunu düşünmektedirler.

Öğretmenlere göre, okul yöneticilerinin toplantı tutanaklarını yönetme becerileri, yıllara göre istatistiksel olarak anlamlı bir farklılı̆a sahiptir $(p=0,00 ; p<0,05)$. Öğretmenlerin 2009 yılındaki toplantı tutanaklarını yönetme becerileri ortalaması 2,19 ve 2021 yılındaki toplantı tutanaklarını yönetme becerileri ortalaması 3,56'dır. Bu bağlamda; araştırmaya 2021 yılında katılan öğretmenler, okul yönetiminin toplantı tutanaklarını yönetme becerilerinin 2009 yılına göre daha olumlu olduğunu düşünmektedirler.

\section{SONUÇ VE ÖNERILER}

Günümüz eğitim kurumlarında yöneticilerin başarıları olabilmeleri, demokratik katılımcı bir atmosfer yaratabilmeleri ve etkili örgütsel bütünleşmeyi sağlayabilmeleri açısından toplantı yönetimini iyi bilmeleri ve en iyi şekilde yönetebilmeleri gerekmektedir ( Altınok V. 2015) Çalışma ortamında bulunan tüm olumsuzlukların tespit edilip çözüm yolu bulmak yine iyi yönetilen toplantılar sayesinde gerçekleşmektedir. Yapılan toplantıların niteliği ve sayısı yönetimde birlikteliği sağlamanın yanısıra örgütteki toplantı kültürünün ve kurum iklimin (Altuntaş, Demirdağ, Ertem, 2020) gelişmesine de katkıda bulunmaktadır. (Doğan, 2013, s. 22). Literatür incelendiğinde, okul yöneticilerinin toplantı yönetimi tutum ve becerilerinin kurumlarda verimi direk etkilediği görülmüştür.

Yöneticinin yeterliliğinin, toplantı kavramını ve çeşitlerini bilmesi, liderlik yeterliliği, planlama, zaman, problem çözme, yönetme, imkân, yer, bütçeleme, tutanak tutma vb. yeterliliği ile ilişkili olduğu görülmüştür. Ancak yönetici seçim sürecinde toplantı tutum ve yeterliliğinin göz ardı edildiği, düşük becerilerin öğretmenler tarafından yöneticiye bakış açısında da olumsuz etkisi olduğu tespit edilmiştir. Bu bağlamda bu araştırmada eğitim sistemimizdeki toplantı yönetimi ile ilgili çalışmalara katkıda bulunmak üzere okul yöneticilerinin toplantı yönetimi ve becerilerinin ne kadarına sahip olduğunu incelemek üzere hipotezler oluşturulmuş ve 2009 ve 2021 yılında yapılan amprik çalışmalar ile öğretmenlerin algıları üzerinden yöneticilerin toplantı yönetim ve becerileri karşılaştırılmıştır. Anket çalışması sonucunda MEB'e bağı okullarda görevli yöneticilerin "Toplantı Yönetimi Tutum ve Becerileri" öğretmenlerin görüşlerine göre değerlendirilmiştir. Cinsiyet, öğrenim durumu ve meslekteki hizmet süresi gibi demografik değişkenler açısından bu görüşlerin anlamlı düzeyde farklılık gösterip göstermediği incelenmiştir.

Araştırma sonucunda elde edilen bulgular hipotezimizi destekler nitelikte olup; öğretmenlerin algılarına göre, okul yöneticilerinin toplantı yönetim becerilerinin yıllara göre istatistiksel olarak anlamlı bir farklılığa sahip olduğunu göstermektedir. Araştırmaya 2021 yılında katılan öğretmenler, okul yöneticilerinin toplantı yönetme becerilerinin 2009 yılına göre zamanı yönetme, salon olanaklarını yönetme, toplantı gündemini yönetme, katılımcıları yönetme, toplantı tutanaklarını yönetme gibi alt boyutlar açısından daha olumlu yönde geliştiği algısındadırlar. Bu sonuçlar göz önünde tutulduğunda zaman içinde gerek hizmet içi eğitimlerle ve gerek üniversitelerle yapılan anlaşmalarla düzenlenen yüksek lisans eğitimleri sonucu okul yöneticilerinin toplantı yönetim becerilerinin artmış olduğu söylenebilir. Demografik yapılara göre bulgularda farklılıklar Milli Eğitim Bakanlığının yönetici stratejileri belirlerken ve eğitim şirketlerinin politika belirleme aşamalarında faydalanmalarına imkan verecektir.

Okul yöneticilerinin "Toplantı Gündemini Yönetme Becerileri”ni öğretmenlerin algılamalarında öğretmenlerin cinsiyete göre farklılaşmaktadır. Kadınların toplantı gündemini yönetme becerileri algıları erkeklerden daha fazla olduğu görülmektedir. Bu durum kadınların daha detaycı bir yapıya sahip olmasından kaynaklanıyor olabilir. Erkek öğretmenlerin toplantı gündemini yönetme becerileri algılarını geliştirmeye yönelik eğitimler düzenlenebilir.

Okul yöneticilerinin "Toplantı Yönetici Becerileri" ve "Toplantı Tutanaklarını Yönetme Becerileri" öğretmenlerin algılamaları da öğretmenlerin eğitim durumuna göre farklılaşmaktadır. Yüksekokul ile lisansüstü eğitim grupları arasında anlamlı farklılığın olduğu ve yüksekokul eğitim seviyesindekilerin daha olumlu düşündükleri sonucuna ulaşılmıştır. Okul yönetimi başarısının okulun başarısında önemli katkısı olduğu görülmektedir. Yöneticilerin toplantıları yönetme becerilerinin daha geniş örneklemlerde karşılaştırılması önerilir.

Okul yöneticilerinin "Toplantı Yönetici Becerileri" ve "Zaman Kontrolü Yönetme Becerileri" öğretmenlerin algılamaları da 
öğretmenlerin hizmet süresine göre farklılaşmaktadır. Buna göre yöneticilerin meslekte geçen süre artışının, tecrübe kazanmanın ve mesleki deneyiminin toplantı yönetimi becerileri üzerinde olumlu etkide bulunduğu söylenebilir.

Okul yöneticilerinin toplantı yönetimi becerileri, zaman yönetimi, salon tesislerini yönetme, toplantı gündemi, katılımcıları yönetme ve toplantı tutanaklarını yönetme boyutları yıllar içinde önemli farklılıklar göstermiştir ve 2009 yılına göre daha gelişmiş olduğu belirlenmiştir.

Tüm bu gelişmeler, okul yöneticilerinin toplantı yönetme tutum ve becerilerini doğru bir şekilde kullanabilmesine katkı sağlamaktadır. Yöneticiler bilgi ve becerilerini yararlı bir şekilde kullandıklarında, öğrencinin geleceği için doğru kararlar alıp, doğru adımlar atacaktır. Okuluna yararlı olan bir yönetici başarılı olacaktır. Yönetimi başarılı olan bir okulun da başarılı olması beklenmektedir. 2009 yılından günümüze uzanan eğitim sürecinde yöneticilerin kendi kişisel gelişimlerini artırmaları, bilgi ve becerilerini doğru bir şekilde işleyebilmeleri eğitim sistemini iyileştirecek ve öğrencilerin başarısını arttırması beklenecektir.

Bütün toplantılar, toplantı yöneticileri ile katılımcılarının birbirleriyle uyumlu çalışmasıyla verimli olabilir (Mısırlı, 2013, s. 1). Bu nedenle okul yöneticilerinin toplantıları yalnızca gerekli kararları almak üzere zorunlu bir görev olarak değil, aynı zamanda katılımcı öğretmenler arasında iletişimi sağlayacak, işbirliğini geliştirecek ve farklı görüşleri demokratik bir şekilde almaya yönelik bir etkinlik olarak görmeleri gerekmektedir. Her toplantıya başlarken okul yöneticilerinin öğretmenlere güvendiklerini ve görüşlerine önem verip desteklediğini hissettirmesi, toplantı sonunda ise gelecek çalışmalar için gereken olanakların nasıl sağlanacağı konusunda bilgi vermeleri tüm katılımcıların içinde bulundukları örgüte aidiyetlerini artıracak, okula ve arkadaşlarına olan bağlııklarını pekiştirecek, tükenmişlik hissini azaltacaktır.

Toplantı yönetimi alanında yapılacak yeni araştırmalarda eğitimde yaşanan dijital dönüşüm sürecinin de dikkate alınması gerektiği açıktır. Eğitimde yaşanan dijitalleşme ile sanal ortamda yapılan toplantılarla ilgili yeni bileşenlerin eklenmesi ve yeni alt boyutlarının belirlenmesine yönelik araştırmalara ihtiyaç duyulmaktadır. Örneğin teknolojik imkânların sunum yöntemlerine katkısı veya uzaktan eğitim ile öğretmenlerin ve okul idarelerinin çevrimiçi platformları tanıması sonucu hızlı toplantı imkânlarının okul yönetimine etkileri, Web 2.0 araçlarının kullanımının hızla yaygınlaştığı günümüzde etkili sunum becerileri ile donatılmış toplantıların okul kültürü ile ilişkileri konularında araştırmaların yapılması litaratüre katkı sağlayacaktır.

\section{REFERANSLAR}

Açıkalın, A.(1995/a), toplumsal kurumsal ve teknik yönleriyle okul yöneticiliği, Ankara: Pegem yayıncılık.

Altınok V. (2015). Competence of school administrators at conducting meetings in educational institutions. EIJEAS Electronic International Journal of Education, Arts and Science, 1(2), 1406163,Ohio, USA. http://www.eijeas.com.

Altuntas, B. , Demirdag, S. ve Ertem H. Y. (2020). Velilerin algılarına göre okul yöneticilerinin yönetim becerileri ile okul iklimi arasındaki ilişkinin incelenmesi. AJER - Academia Eğitim Araştırmaları Dergisi 5(2), 254-269. https://dergipark.org.tr/pub/egitim e-ISSN $2619-9351$.

Avcı, U. ve Seferoglu, S. S. (2011). Bilgi toplumunda öğretmenin tükenmişliği: teknoloji kullanımı ve tükenmişliği önlemeye yönelik alınabilecek önlemler. Akdeniz Eğitim Araştırmaları Dergisi. 9, 13-26. http://yunus.hacettepe.edu.tr/ sadi/yayin/Avci-Seferoglu_MJER-20119_Tukenmislik.pdf, Erişim tarihi 20.10.2017.

Balcı, A.(1995). Örgütsel gelişme, Ankara: Pegema Yayın Dağııım

CalıSkan, A.(2017). Okul yöneticilerinin algilarina göre ilçe milli eğitim müdürlerinin toplanti yönetimi becerileri. Yayınlanmamış Yüksek Lisans Tezi, istanbul Sabahattin Zaim Üniversitesi Sosyal Bilimler Enstitüsü Eğitim Bilimleri Anabilim Dalı.

Calıskan U.(2009). Okul yöneticilerinin toplantı yönetimi ile ilgili tutum ve becerilerinin öğretmenler tarafından algılanması. Yayınlanmamış Yüksek Lisans Tezi, Maltepe Ün. Sosyal Bilimler Enstitüsü Eğitim Bilimleri Ana Bilim Dalı.

Dogan, A. A. (2013). Toplantı ve sunu teknikleri, Eskişehir: Anadolu Üniversitesi Yayınları

Doyle M, ve Stratus D. (1998). Verimli bir toplantı nasıl yapılır?,(Çev.:Ramazan Saruhan), İstanbul:Nesil Yayınları.

Dunsing, Richard J. (1989). toplantı sanatı, (Çev.:Fatoş Dilber), İstanbul:İlgi Yayıncılık.

Ersoy, S.(2006). Ilköğretim okullarında yönetici ve öğretmenler arasındaki iletişim sorunları, Yayınlanmamış Yüksek Lisans Tezi, Yüzüncü Yıl Ün. Sosyal Bilimler Enstitüsü Eğitim Bilimleri Ana Bilim Dalı.

Icoz, O. (1998). Seyahat acenteleri ve tur operatörlüğü yönetimi, Genişletilmiş 2. Baskı, Ankara:Turhan Kitabevi. 
Issever, C. vd. (2001). Toplantı yönetimi. Ankara: MEB Erkek Teknik Öğretim Genel Müdürlüğü Daire Başkanı.

Karasar, N.(2007). Bilimsel araştırma yöntemi, Ankara :Nobel Yayın Dağıtım.

Linkemer, B. (1993). Verimli toplantı nasıl yapılır?,(Çev.:Doğan Şahiner), İstanbul:Rota Yayın Yapım Ltd.

Mısırlı, İ. (2013). Toplantı yönetimi, Ankara: Detay Yayıncılık

Morgan, N.(2006). Toplantı yönetimi,( Çev.:Ahmet Kardam), İstanbul:Optimist Yayıncılık.

Padem, H., Göksu A. ve Konaklı Z., (2012). Araştırma yöntemleri - SPSS uygulamalı, International Burch University: Sarajevo.

Payne, J. and S.(1998). Bir haftada başarılı toplantı yönetimi, (Çev.:Emel Köymen), İstanbul:"Globus" Dünya Basımevi.

Şişman, M. (2004). Oğretim liderliği. Ankara: Pegema Yayıncılık.

Tavmergen, I. Pınar ve Aksakal, E. Günlü, (2004). Kongre ve toplantı yönetimi, Ankara: Seçkin Yayıncılık.

Taymaz, H. (2003). Ilköğretim ve ortaöğretim okul müdürleri için okul yönetimi. Ankara: Pegema Yayıncılık.

Toplantı. Türk Dil Kurumu güncel Türkçe sözlük içinde. Erişim adresi: https://sozluk.gov.tr/

Tümkaya, S. (2005). Öğretmenlerin sınıf içi disiplin anlayışları ve tükenmişlikle ilişkisi. Kuram ve Uygulamada Eğitim Yönetimi Dergisi, 44, 549-568.

Türkiye'de Öğretmen Eğitimi ve İstihdami: Mevcut Durum ve Öneriler. (2017). Hacettepe Üniversitesi Eğitim Fakültesi. Erişim Adresi: http://www.egitim.hacettepe.edu.tr/belge/OgretmenEgitimi-istihdam_Raporu.pdf

Yurdakul, S., Gür, B. S., Çelik, Z. ve Kurt, T. (2016). Öğretmenlik Mesleği ve Mesleğin Statüsü. Ankara: Eğitim-Bir-Sen Stratejik Araştırmalar Merkezi. Erişim adresi: http://www.ebs.org.tr/ebs_files/files/yayinlarimiz/mesleginstatusu_web.pdf, 